\title{
RANĚ STŘEDOVĚKÁ KERAMIKA Z HRADIŠTĚ KNĚŽÍ HORA U KATOVIC (OKRES STRAKONICE)
}

\author{
LADISLAV ČAPEK - PETR MENŠÍK
}

\begin{abstract}
Abstrakt: Kněži hora u Katovic (okr. Strakonice) patři mezi největši jihočeská raně středověká hradiště z 9. až počátku 10. století. Dosavadni poznáni tohoto hradiště vycházelo předevšim z výzkumu B. Dubského z roku 1946. V poslednich letech je hradiště systematicky zkoumáno pracovniky Katedry archeologie Západočeské univerzity v Plzni prostřednictvím nedestruktivních a málo destruktivních metod. V letech 2016-2017 proběhly na akropoli hradiště vzorkovaci sondáže vyvolané porušením lokality lesním hospodářstvím a nelegálními aktivitami hledačủ kovi̊. Z výzkumu byly získány početněji výraznějši soubory raně středověké keramiky, jejiž podrobný rozbor významně přispívá k datování lokality do středohradištního obdobi s těžištěm v 9. století, které podporuje i radiokarbonové datování uhlikio pocházejícich z horni destrukce dřvohlinité hradby.
\end{abstract}

Klićová slova: hradiště - raný středověk - střední doba hradištní-keramika-jižni Čechy.

\section{Early medieval pottery from the Kněži hora hillfort, near Katovice (Strakonice district)}

Abstract: Kněži hora near Katovice (Strakonice district) is one of the largest south-Bohemian early medieval hillforts, dating from the 9th-early 10th century. The existing information about the hillfort was chiefly based on research carried out by B. Dubský in 1946. In recent years the hillfort has been systematically investigated by experts from the Department of Archaeology of the University of West Bohemia, Plzen by means of non-destructive and the least destructive methods. Test digs were conducted on the hillfort acropolis in 2016-2017, triggered by intrusion in the form of forestry work and illicit metal detecting. The excavations yielded large series of early medieval pottery, the detailed analysis of which significantly contributed to the dating of the site to the Middle Hillfort period with its heyday in the 9th century, also supported by the radiocarbon dating of cinders from the destructed upper section of the timber and earth rampart.

Key words: hillfort - early Middle Ages - Middle Hillfort period - pottery - south Bohemia.

\section{1 Úvod}

Kněží hora u Katovic (okr. Strakonice) patří mezi největší jihočeská raně středověká hradiště. Nachází se v oblasti středního Pootaví a společně s další trojicí menších hradišt' Libětice, Hradec u Řepice a Hradec u Němětic tvoří výraznou sídelní komoru a „mocenský trojúhelník“ raně středověkého osídlení z průběhu 9. století a počátku 10. století (obr. 1). Tato hradiště na počátku 10. století zanikla, jak dokládají spálené konstrukce dřevohlinitých hradeb. Dosavadní interpretace zmiňují zhroucení zdejšího teritoria pod vpády Mad’arů či v rámci jejich spoluúčasti při sjednocování Čech Přemyslovci v prvních desetiletích 10. století (Lutovský 1999; 2011, 205-213; nejnověji Kouřil 2016, 124). Oblast jižních Čech ležela v bezprostředním sousedství Velkomoravské ŕíše, karolinské Východní marky a Bavorska; nelze vyloučit, že k zániku hradišt' mohlo dojít v souvislosti s neklidnými poměry na konci 9. a počátku 10. století. Mad’aři mohli vystupovat na různých stranách konfliktu mezi soupeřícími stranami o mocenské ovládnutí středního Podunají, včetně oblastí jižních Čech (např. Wihoda 2016, 146-157; Zehetmayer 2016, 82-90).

Bohužel k oblastem jižních Čech písemné prameny na konci 9. a počátku 10. století nepodávají žádná svědectví. Hradiště Kněží hora dosud nebylo předmětem systematického archeologického průzkumu. I když zde probíhala řada aktivit v minulosti (drobné sondáže, povrchové průzkumy), dosavadní archeologické poznání je velmi omezené, stejně jako datování počátků a zániku hradiště, kladené do období konce 8 . až počátku 10. století. Jedním z datovacích opor mohou být nálezy raně středověké keramiky, které doposud měly povahu malých „nestratifikovaných souborů“ bez bližších nálezových okolností. Teprve v posledních letech proběhl na akropoli systematický archeologický výzkum Katedry archeologie Západočeské univerzity ve 


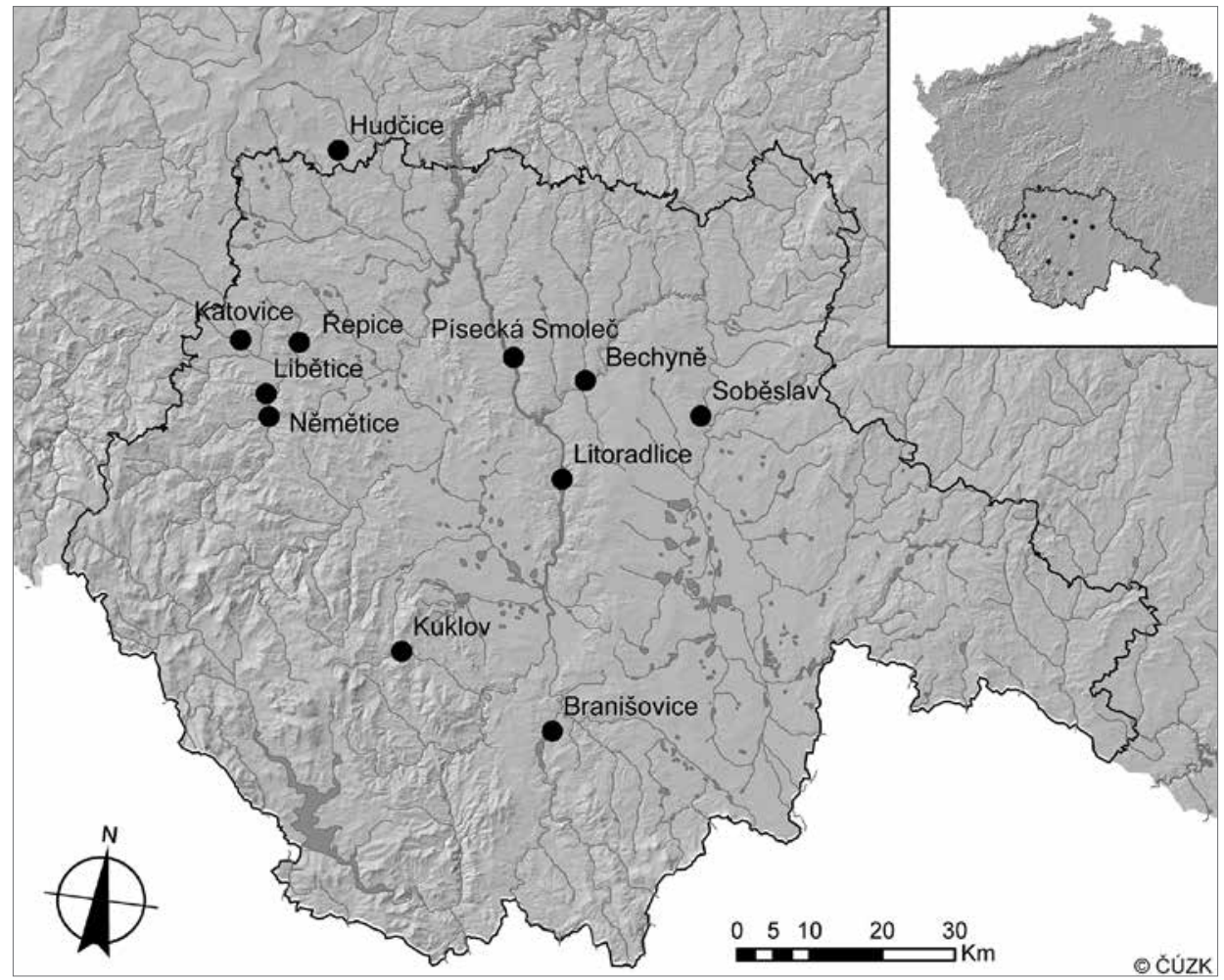

Obr. 1. Raně stř̌edověká hradiště 9. a počátku 10. století v jižních Čechách. Vytvořil L. Čapek.

Abb. 1. Frühmittelalterlicher Burgwall vom 9. und Anfang des 10. Jahrhunderts in Südböhmen. Erstellt von L. Čapek.

spolupráci s Muzeem středního Pootaví ve Strakonicích vyvolaný těžbou dřeva a nelegálními aktivitami hledačů kovů, který přinesl reprezentativní a početné nálezy raně středověké keramiky, které byly předmětem podrobného rozboru.

\section{Historie dosavadního poznání}

Až do 18. století byla katovická hora nazývána Hradištěm. Př́ivlastek „Kněži“ označuje majitele zdejších pozemků, kterým se v pobělohorské době stala katovická fara (Dubský 1928, 70-72; 1949, 586; Sklenář 2011, 115-116). F. X. M. Zippe v letech 1824-1825 pro hraběte Štemberka vyhodnotil několik hradišt' a rukopisně popsal i Kněží horu u Katovic (Sklenář 2012, 514). Lokalita je v popředí archeologického zájmu již od druhé poloviny 19. století, i když informace o zde proběhlých výzkumech a průzkumech jsou velmi torzovité (souhrnně Sklenář 2011, 115117, Tab. V:4-5). F. Beneš prokopával valy hradiště v 60. letech 19. století na popud J. E. Vocela (Beneš 1970, 223). Lokalitu navštívil i A. Č. Ludikar, který na několika místech valů „sbíral spečenou hlinu“", hradiště poté zobrazil i na první archeologické mapě Strakonicka (Vocel 1865, obr. 7; Sklenář 2007, obr. 7-8). I přes výrazné opevnění však bylo hradiště Katovice zachyceno pouze v náznacích až na druhém vojenském mapování z let 1836-1852. ${ }^{1}$ První schematické zobrazení lokality publikoval K. Špaček v roce 1861 (Špaček 1861, 27), následují další plány J. N. Woldřicha (1874) a J. L. Píče (1909), ovšem ještě bez přesnější geodetické dokumentace.

1 Viz http://oldmaps.geolab.cz/map_viewer.pl?lang=cs\&map_root=2vm\&map_region=ce\&map_list=W_14_II, cit. 2. 11. 2018. 
Katovické hradiště přitahovalo v 19. a první polovině 20. století také celou řadu regionálních umělců z řad básníků a maliřru (Fröhlich 1990, 105). V centrální části plošiny bylo v minulosti sbíráno množství kamene na stavbu domku a zdi okolo farní budovy, což mělo údajně zničit základy větší kamenné stavby.

Menší archeologický výzkum provedl následně B. Dubský v roce 1946 za pomoci řídícího učitele Koláře. Fotografickou dokumentaci provedla Jihočeská zbrojovka ve Strakonicích (Ing. Schier a Ing. Hurich). Zaměření a vytvoření prvního geodetického plánu lokality vzniklo zásluhou M. Dubského (Dubský 1949, 587, obr. 25). V př́íkopu mezi plošinou akropole a valem byla B. Dubským položena sonda o rozměrech $1,5 \times 2$ metry, $v$ níž byla pravděpodobně odhalena kulturní vrstva s drobnými kameny dosahující hloubky $30-40 \mathrm{~cm}$. Byly v ní nalezeny raně středověké střepy a jeden pravěký střep (Dubský 1949, 594, obr. 29:1, 3-6). Další sonda o rozměrech $2 \times 1$ metr byla situována v př́ikopu nad srázem k řece Otavě, kde bylo v kulturní vrstvě objeveno opět několik raně středověkých střepů (Dubský 1949, 595, obr. 29:9-10, 12). Výraznější osídlení bylo zjištěno pouze na předhradích. Na vnitřním předhradí se podařilo odhalit část zahloubené chaty o rozměrech $3 \times 2$ metry (Dubský 1949, obr. 29:11, 13) a na vnějším předhradí v blízkosti brány pec. Drobná kolekce nálezů z výzkumu B. Dubského byla již v minulosti publikována (Michálek 1981, obr. 25:14-22, 26:1-22; Lutovský 1993, 3-4, obr. 9:4-9). Další drobné povrchové sběry na lokalitě byly provedeny v 80 . letech 20 . století. Nejnovější plán lokality pochází z roku 2006 a byl vytvořen při mapování valů pomocí GPS. Byla také zdokumentována kleštovitá brána s dovnitř zataženými křídly a byl vytvořen její 3D model (John-Rytír 2007, Fig. 5). Další průzkumy lokality proběhly až v letech 2016-2017.

\section{Archeologický výzkum v letech 2016-2017}

Již několik let probíhají v prostoru památky nelegální průzkumy pomocí detektoru kovů a poměrně intenzivní lesnické činnosti spojené s lesní těžbou. V průběhu počátku roku 2016 byly na lokalitě identifikovány četné polomy a vývraty, které s následným stahováním dřeva porušily některé nálezové situace po celé ploše hradiště. Tyto skutečnosti vedly k realizaci záchranného archeologického výzkumu Katedry archeologie Západočeské univerzity v Plzni ve spolupráci s Muzeem středního Pootaví ve Strakonicích v letech 2016-2017. Ve dvou sezónách se podařilo odkrýt 12 archeologických sond rozmístěných na akropoli hradiště, které byly položeny v místech výraznějšího narušení. V několika menších sondách $(1 \times 1$ metr $)$ bylo sledováno historické nadloží lokality (sondy $2,4,9,10,11,12$ ). Sondy 1,5 a 8 nasedaly bezprostředně na patu severního valu akropole. V nich byly odhaleny zbytky destruované konstrukce kamenné hradby. $\mathrm{V}$ jednom př́padě byla objevena kumulace kamenů, lze o ní teoreticky uvažovat jako o zbytku konstrukce stavení (?) na okraji hradby akropole. V těchto sondách bylo také objeveno několik zahloubených objektů sídlištního charakteru, bohužel bez datovacího archeologického materiálu. Rozpadlá kamenná konstrukce se nacházela taktéž v sondě $6 \mathrm{v}$ jihovýchodní části akropole. Ta by mohla představovat západní konec kamenného ohrazení, koridoru, kterým se vstupovalo do prostoru akropole. Zajímavým objevem byla situace v sondě $3 \mathrm{~s}$ výrazným nepravidelným objektem o rozměrech $120 \times 80 \mathrm{~cm}$ s hloubkou přes $150 \mathrm{~cm}$. V jeho výplni bylo zjištěno větší množství větších kusů mazanice pocházejících z dřevohlinité stavby nejasného charakteru nacházející se v blízkém okolí. V západní části akropole se nachází pravděpodobně novodobý průkop valem (obr. 2:3). Jeho boční stěna byla v roce 2017 porušena lesní technikou, proto zde byl val začištěn po úroveň porušení (sonda 7). Podařilo se odhalit zbytky čelní kamenné plenty s vnitřní dřevěnou roštovou konstrukcí. Místy bylo možné pozorovat červenou přepálenou kamennou sut's přepálenou hlínou s otisky prutů. Dá se předpokládat, že alespoň část hradby zanikla požárem. Z dřevěné konstrukce byly odebrány vzorky na datování C14 (určil RNDr. I. Světlík; obr. 10-11). Radiokarbonové datování po kalibraci ukazuje na interval od třetí třetiny 8. století do konce 9 . století, s prŕípadným přesahem u vzorku č. 2 do poloviny 10 . století (více Menšík-Král 2017; Menšík et al. v prŕípravě). 


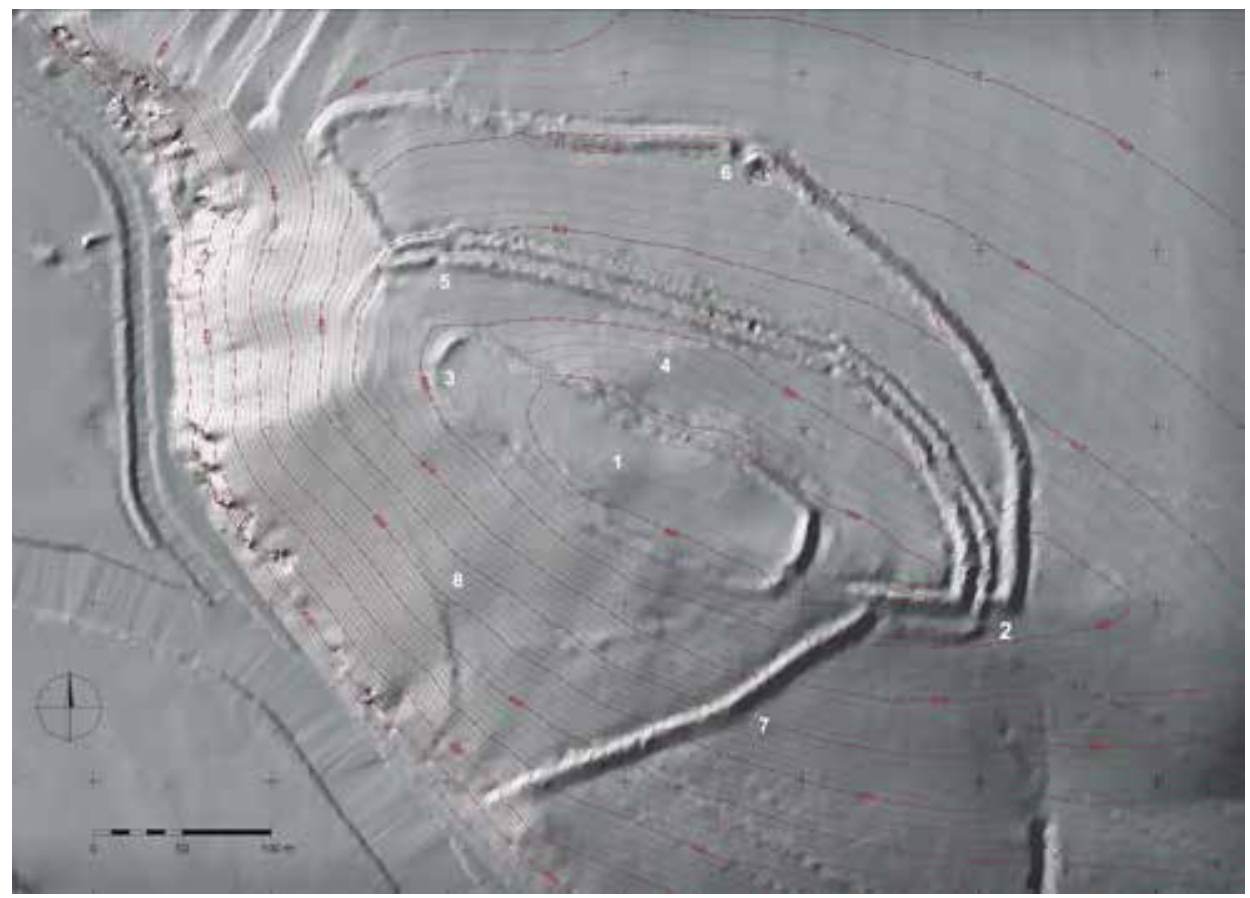

Obr. 2. Plán hradiště Kněží hora u Katovic. Digitální stínovaný model reliéfu. Vytvořili P. Hlavenka a P. Menšík.

Abb. 2. Plan des Burgwalls Kněží hora bei Katovice. Schattiertes digitales Reliefmodell. Erstellt von P. Hlavenka und P. Menšík.

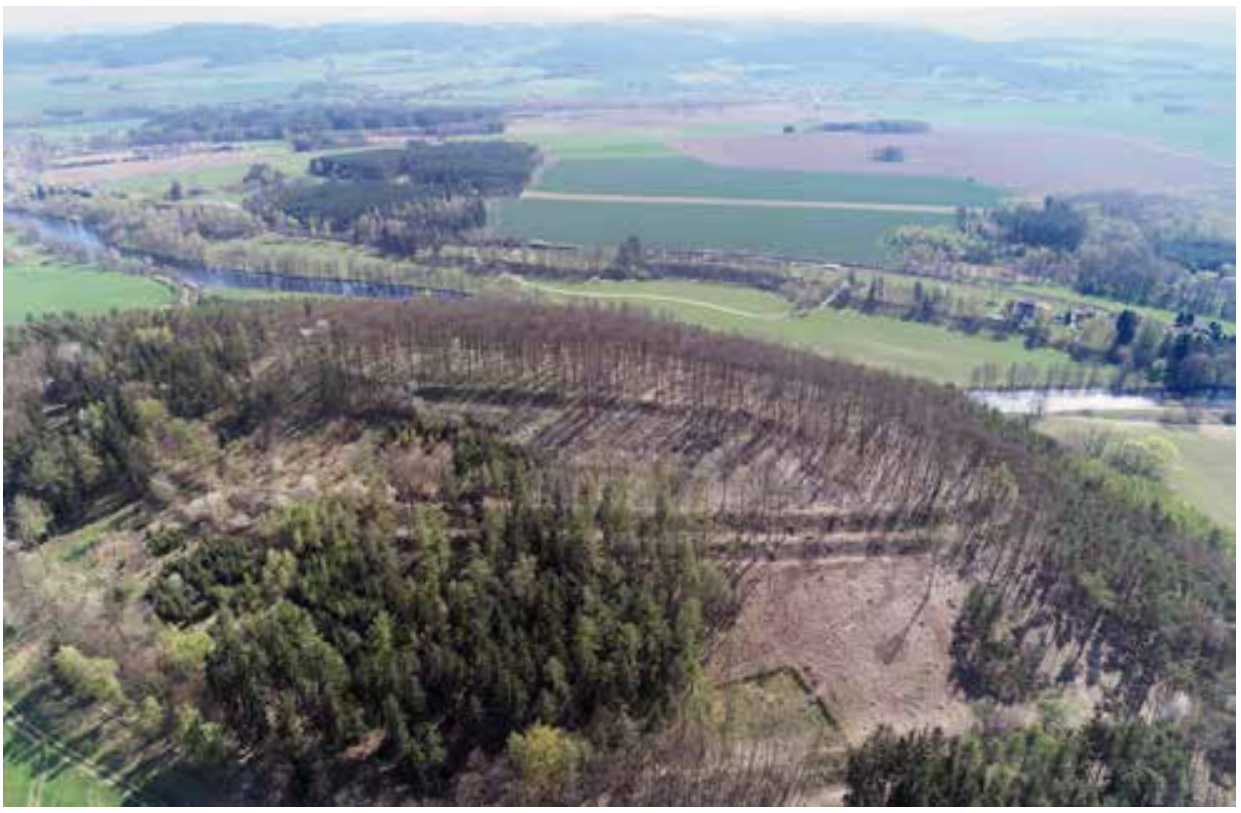

Obr. 3. Pohled na akropoli a vnitřní předhradí hradiště Kněží hora u Katovic. Foto J. Vidman.

Abb. 3. Blick auf die Akropolis und die innere Vorburg des Burgwalles Kněží hora bei Katovice. Foto J. Vidman. 
Při archeologickém výzkumu byly odebírány vzorky pro environmentální analýzy, které jsou v současné době ve zpracování. Kromě záchranného archeologického výzkumu byla lokalita podrobena detailnímu povrchovému průzkumu - kromě hradiště bylo sledováno i širší okolí. Z tohoto důvodu byla zpracována data z leteckého laserového skenování a byl vytvořen podrobný digitální stínovaný model reliéfu (obr. 2). Zároveň proběhlo detailní snímkování hradiště pomocí dronu (obr. 3). Z archeologického výzkumu byl získán soubor archeologických nálezů, z nichž nejstarší doklady sídlištních aktivit na katovické hoře můžeme klást již do období pravěku, konkrétně již do závěru paleolitu a mezolitu, dále do eneolitu, pozdní doby bronzové, doby halštatské a laténské (Menšík-Procházka-Král 2018). Nejpočetněji jsou však zastoupeny nálezy keramiky, kovových předmětů a zvírrecích kostí, které je možné spojit s existencí raně středověkého hradiště.

\section{Popis hradiště}

Na základě dat získaných díky leteckému laserovému skenování byl proveden v prostoru hradiště v roce 2016 podrobný povrchový průzkum zaměřený na detailní popis terénních reliktů. Na základě kombinace obou přístupů bylo zjištěno několik doposud neznámých skutečností o této lokalitě. Hradiště dosahující rozlohy téměř 8 ha (pokud bereme v potaz akropoli, vnitřní a vnější předhradí) má velmi dobře dochovaný složitý systém opevnění. To tvoří oválný tvar o rozměrech $380 \times 220$ metrů. Z jižní strany bylo hradiště chráněno příkrým svahem, z ostatních stran pásy několikanásobných hradeb. Ústřední část akropole zaujímá protáhlou vrcholovou plošinu, která je opevněna po celém svém obvodu (obr. 2:1). Původní př́istup do akropole lze předpokládat po pozvolném hřbetu z východu, kde se setkávají všechny fortifikační systémy hradiště (obr. 2:2). Západní přerušení valu do akropole je s největší pravděpodobností recentního původu (obr. 2:3). Na akropoli navazuje ze severní strany vnitřní předhradí, které je členěno do méně výrazných terasovitých stupňủ (obr. 2:4). Od vnějšího předhradí na severu je odděleno dvojitým pásem valů a př́kopů. Vstup mezi oběma prostory se nachází v západní části areálu (obr. 2:5). $\mathrm{V}$ jeho př́ípadě nelze dnes pozorovat žádné vnitřní členění. Ze severu je vymezeno výrazným valem, který dosahuje délky 640 metrů a výšky až 6 metrů. Vstup do předhradí se nachází na severu, jedná se o čelní bránu s mírně zataženými křídly (obr. 2:6).

Další fortifikace hradiště vychází z blízkosti východního vstupu do akropole a jihozápadním směrem klesá do nivy řeky Otavy (obr. 2:7). Ze západního konce akropole klesá méně výrazná terénní hrana jihovýchodním směrem a nad údolím Otavy se stýká s výše zmíněným valem (obr. 2:8). V tomto případě by se mohlo jednat o další areál bezprostředně související s hradištěm (více Menšík-Král 2017; Menšík et al. v př́ípravě). Určitá forma fortifikačního systému by se mohla nacházet na zemědělsky využívaném poli severně od hradiště. Dodnes je v terénu viditelná terénní hrana možného valu s kumulací kamenné destrukce, i když na některých místech již není patrné jeho pokračování, napojení na stávající val či vstupní bránu (více s vizualizací Menšík-Plzák 2018).

\section{Raně středověká keramika z Kněží hory}

Z hradiště Kněží hora u Katovic bylo již v minulosti získáno několik souborů raně středověké keramiky. Především se jedná o keramické nálezy z výzkumu B. Dubského z roku 1946, dnes uložené v Muzeu středního Pootaví ve Strakonicích a v Národním muzeu v Praze. Bohužel k nim dnes nelze dohledat bližší informace, ani přesně lokalizovat místo výzkumu. Výkopy, ze kterých byla získána raně středověká keramika, byly prováděny na severozápadní straně vnitřního předhradí nad př́íkopem prvního valu, kde byl zjištěn zahloubený objekt, interpretovaný jako strážní chata (?), dále v prŕíkopu mezi vrcholovou plošinou (akropolí) a valem a v př́ikopu nad srázem k Otavě a také ve východní části prvního předhradí (Dubský 1949, 593-597, obr. 29; srov. Lutovský 2011, 160). Keramika z výzkumu B. Dubského na hradišti v Katovicích byla publikována v katalogu pravěké sbírky Muzea středního Pootaví ve Strakonicích (Michálek 1981, 

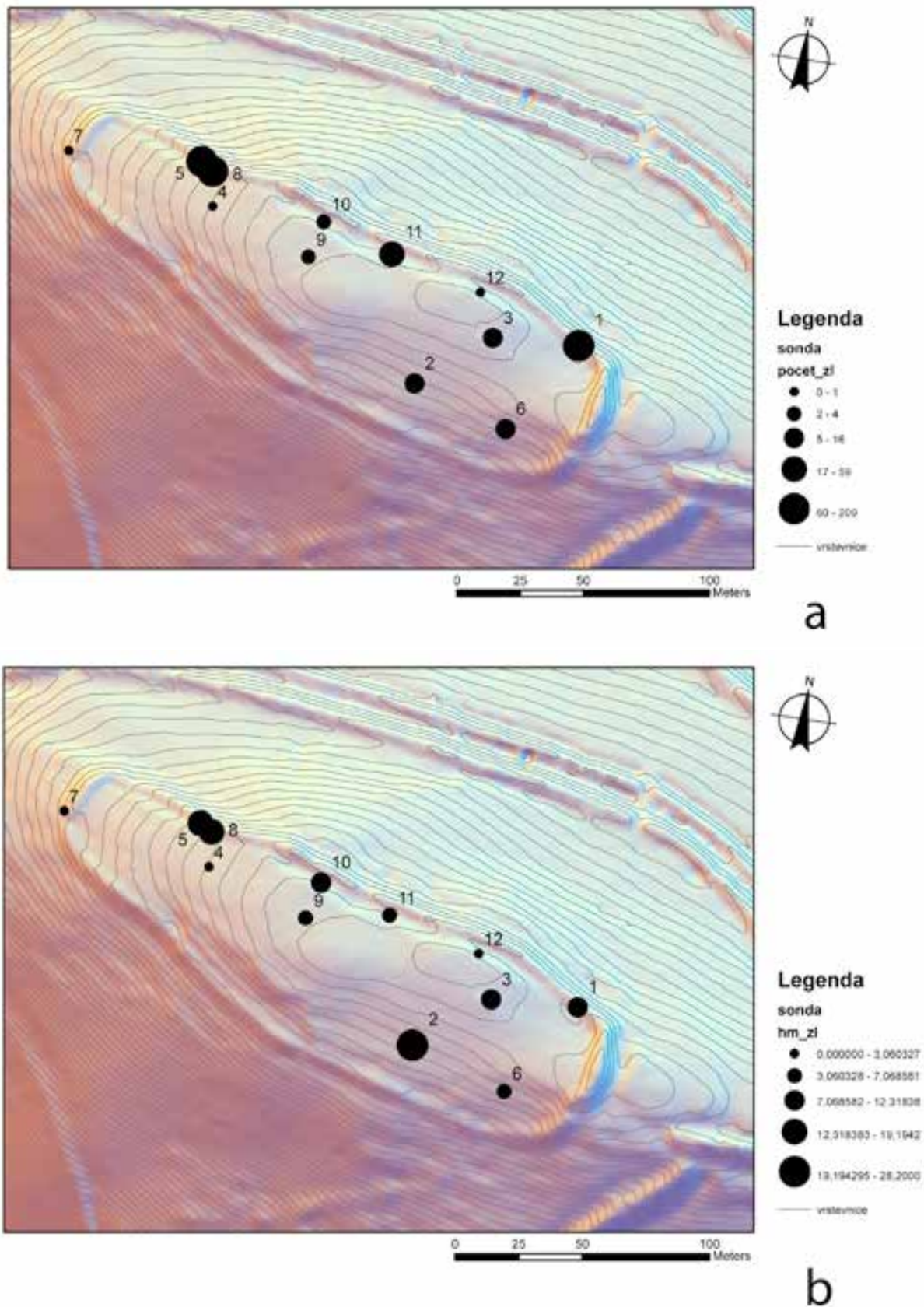

Obr. 4. Distribuce a kvantifikace keramiky v rámci sond z výzkumu 2016-2017. a - počet zlomkủ, b - průměrná hmotnost. Vytvořil L. Čapek.

Abb. 4. Verteilung und Quantifizierung der Keramik der im Rahmen der Grabung von 2016-2017 durchgeführten Sondierungsgrabungen. a - Anzahl der Fragmente, b - durchschnittliche Masse. Erstellt von L. Čapek. 

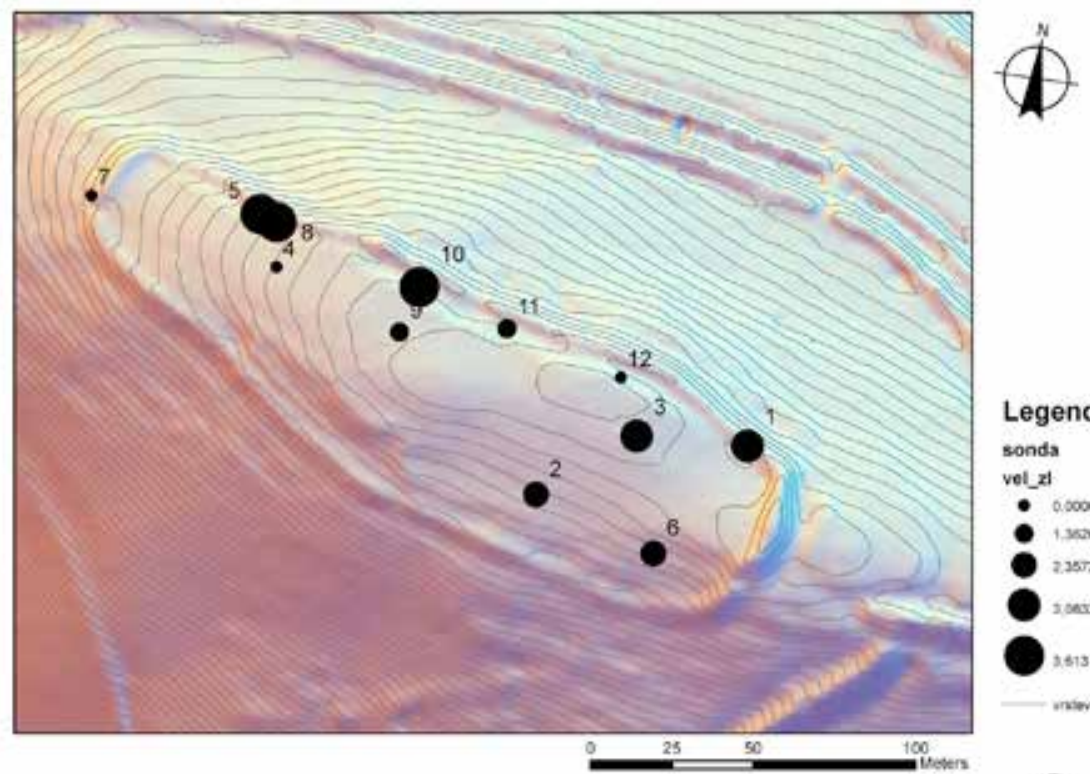

\section{Legenda}

sonda

vel_zil

- 0.000000-1,360ez?

C. 1.30xat-zastzas

$2.250250 \cdot 2$ cesast

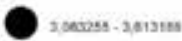

D. $313187-4,000000$

snievise

C
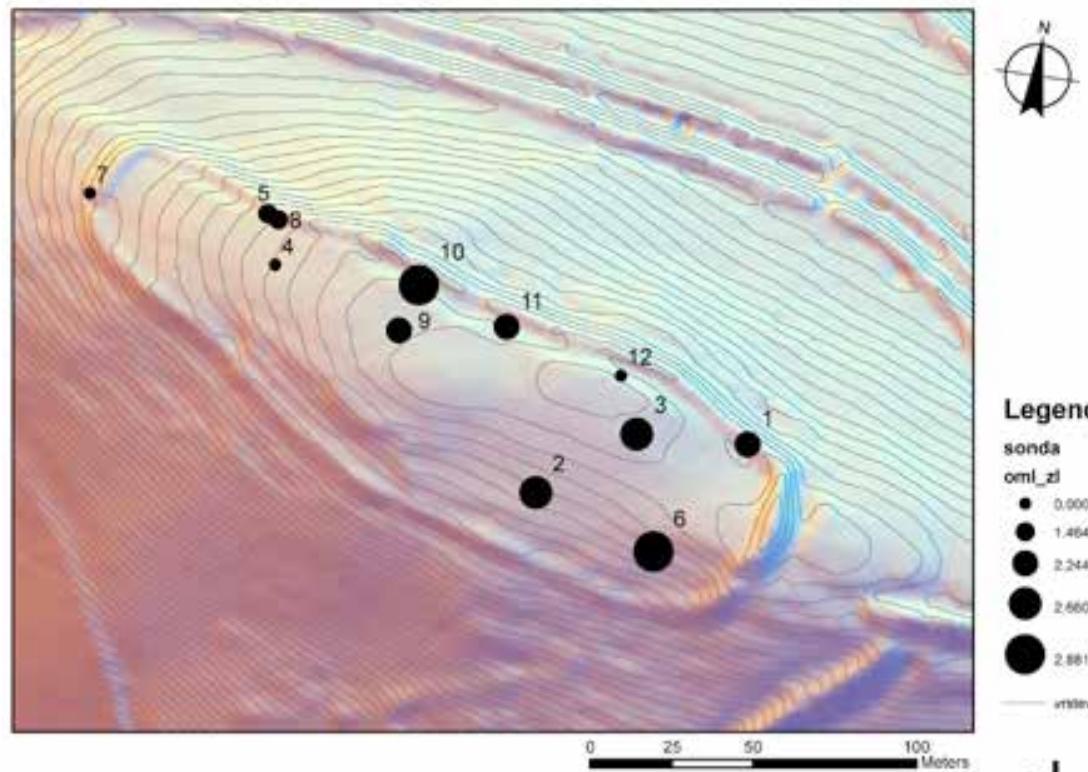

\section{Legenda}

sonda

omi_zl

- 0.000000 indesta

- 1,464t5s-224arst

234atse-2.560ess

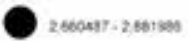

C2sinat +2000000

mimnces

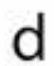

Obr. 4. Distribuce a kvantifikace keramiky v rámci sond z výzkumu 2016-2017. c - velikost zlomkủ, d - omletost. Vytvořil L. Čapek.

Abb. 4. Verteilung und Quantifizierung der Keramik der im Rahmen der Grabung von 2016-2017 durchgeführten Sondierungsgrabungen. $\mathrm{c}$ - Größe der Fragmente, $\mathrm{d}$ - Scherbenabrieb. Erstellt von L. Čapek. 


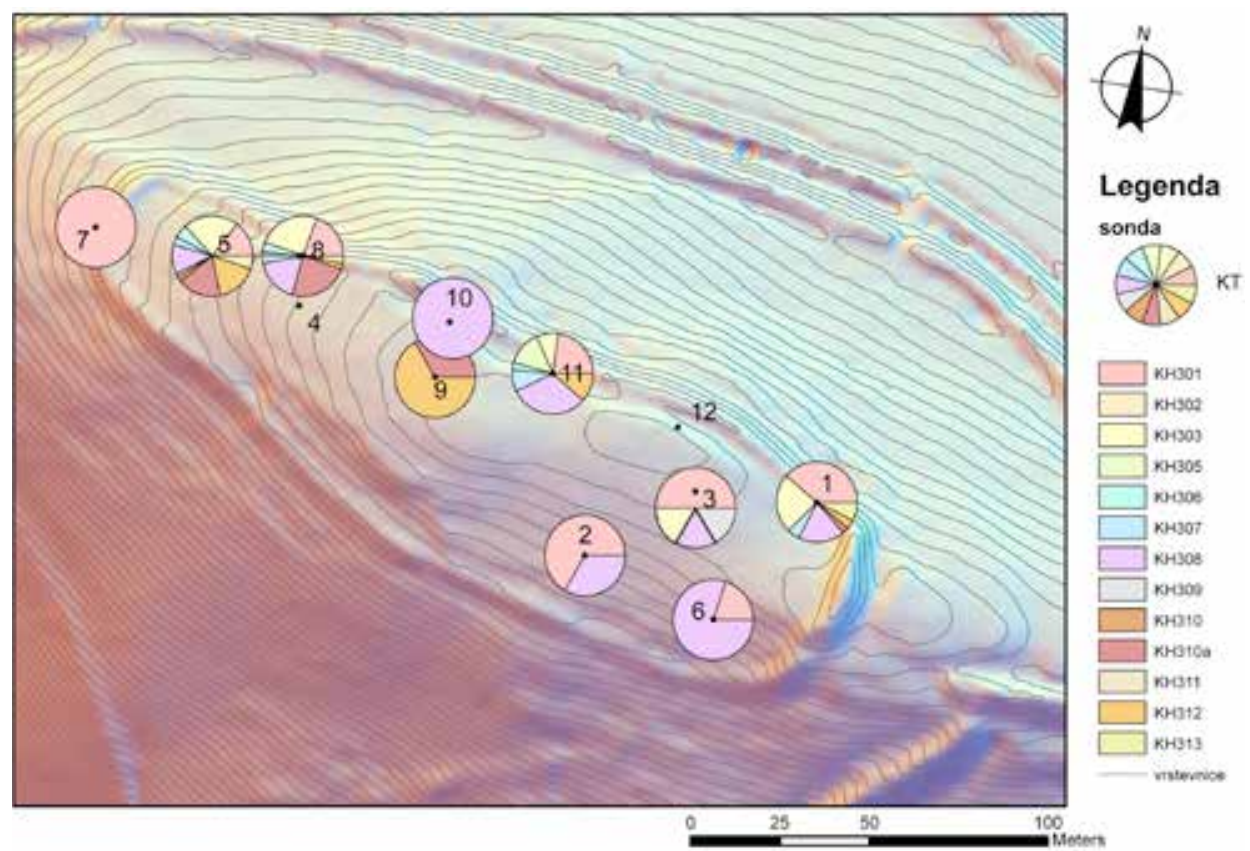

Obr. 5. Distribuce keramických tř́íd. Vytvořil L. Čapek.

Abb. 5. Verteilung der Keramikklassen. Erstellt von L. Čapek.

tab. 24:14-22. 26:1-22) a katalogu raně středověké keramiky z jižních Čech, nacházející se ve sbírkách Národního muzea v Praze (Lutovský 1993, Taf. 9:4-9).

Další nepočetné soubory raně středověké keramiky pocházejí z povrchových sběrů z 80 . let 20. století přímo z akropole hradiště nebo z jeho svahů. Početnější soubory keramiky byly získány teprve až v posledních době, a to díky záchrannému archeologickému výzkumu z let 2016 a 2017 (viz kapitola 3).

\subsection{Metoda zpracování raně středověké keramiky}

Předmětem zpracování se staly soubory raně středověké keramiky, které byly získány při starším výzkumu B. Dubského v roce 1946, z povrchových sběrů na hradišti (dnes uložených v Muzeu středního Pootaví) a záchranného archeologického výzkumu v letech 2016-2017. Celkem bylo zpracováno 589 zlomků keramiky. Soubory pocházející ze sond se lišily počtem, průměrnou hmotností, velikostí a stavem zachovalosti (abraze) zlomků - posuzováno podle zaoblenosti hran (1 - ostrohranné zlomky, 2 - částečně omleté, 3 - omleté, obr. 4:a-d). Nejpočetnější soubory keramiky pocházely ze sond 1 ( $81 \mathrm{zl}$.), 5 (210 zl.) a 8 (137 zl.) na hraně akropole u paty severovýchodního valu. Jednalo se o zlomky s vyšší průměrnou hmotností, velikostí a s nízkou abrazí (tj. vyšším počtem ostrých hran). Lze tedy předpokládat, že pocházejí z vrstev, u nichž nedošlo k výraznému narušení. U zlomků keramiky, zejména ze sondy 8 bylo patrné, že pocházely pouze z několika typů nádob (tab. 5 a 6 ).

Všechny keramické zlomky byly podrobeny deskripci keramických tříd/skupin a technologických znaků, dále byla věnována pozornost morfologii okrajů a charakteru výzdoby. Při zpracování bylo přihlédnuto ke zpracovaným souborům raně středověké keramiky z hradiště Hradec u Němětic (Michálek-Lutovský 2000, 214-222). 


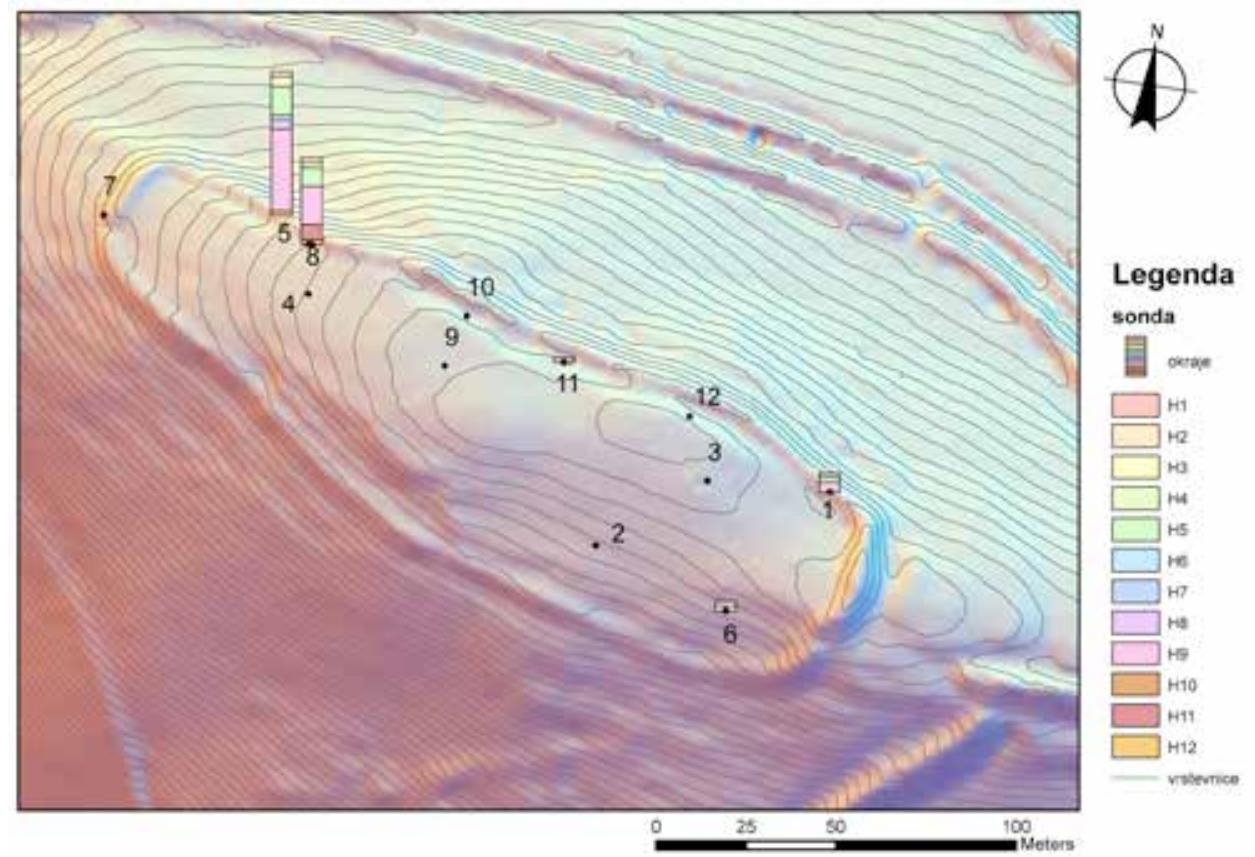

Obr. 6. Distribuce okrajů hrnců. Vytvořil L. Čapek.

Abb. 6. Verteilung der Topfränder. Erstellt von L. Čapek.

\subsubsection{Deskripce keramických třid}

U raně středověké keramiky z Kněží hory jsme pozornost soustředili na deskripci keramických třrid a technologických znaků. U keramických tříd byly makroskopicky sledovány kategorie druhu a velikosti ostřiva, charakter úpravy povrchu, výpal a barva. Za určující kritéria k rozlišení jednotlivých tříd považujeme především druh a velikost ostřiva. Výpal byl ve většině prŕípadů oxidační. Keramické třídy byly jednotně kódovány podle alfabetického a numerického systému - KH označuje lokalitu (Kněží hora) a číslo 3xx vyjadřuje jednotlivé druhy keramických tř́íd. Sledován byl i vztah keramických tř́íd k morfologii okrajových profilací a k zdobeným výdutím. V kresebné dokumentaci keramiky je uvedena př́slušnost fragmentu ke keramické tř́idě. Soupis keramických tříd je uveden na konci práce.

Celkem bylo rozlišeno 13 keramických tříd lišících se od sebe technologií, množstvím příměsí (ostřiva) i charakterem výpalu. Největší zastoupení měly třídy KH303 (23\%), KH301 (19\%), KH308 (18\%) a KH310a (12\%). Distribuce keramických tř́́d v rámci jednotlivých sond ukazuje obr. 5. Keramika obsahovala značné množství mikroskopických příměsí (ca od 1 do $2 \mathrm{~mm}$ ) - písku, dalších hornin (KH301, KH310a) a u některých tříd (KH303, KH308) i hojně stříbřité slídy (muskovitu), nebo zlatavé slídy (biotitu). U žádného z keramických zlomků nebyla zjištěna přítomnost grafitu v keramické hmotě. Středně tvrdý výpal keramiky probíhal za nižších teplot (max. do $800^{\circ} \mathrm{C}$ ) a atmosféra výpalu byla oxidační. Barva střepu byla oranžovookrová, světle hnědá až šedohnědá. Na lomu většiny stř̌epů bylo zjištěno černé jádro, což ukazuje, že při výpalu nedošlo k dokonalému vyhoření uhlíku a organických příměsí. Na vnějším povrchu nebyly pozorovány stopy po engobě v podobě jemně plavené vrstvy hlíny či jiných úpravách povrchů. Na žádném z dochovaných den nebyly doloženy technické značky - otisk osy kola.

$\mathrm{Na}$ celkem 12 keramických zlomcích byly pozorovány stopy po obtáčení v podobě charakteristického zvlnění vnitřního povrchu a ve třech případech stopy tahu prstů na vnitřním 
povrchu. Stopy po obtáčení byly pozorovány také na vnějších stranách okrajů. Na dvou dnech byla doložena př́ítomnost podsýpky.

\subsubsection{Morfologie okrajů}

Dalším důležitým sledovaným kritériem na raně středověké keramice byl způsob profilace a utváření okrajů nádob. Při jejich posuzování bylo přihlédnuto k publikovanému typáři okrajů z Hradce u Němětic (Michálek-Lutovský 2000, 217, obr. 80).

V keramických souborech bylo zastoupeno celkem 74 okrajů náležících bezuchým hrncům, u některých okrajů se dochovala i delší křivka profilace, včetně části podhrdlí. Hrnce měly zpravidla plynulý přechod hrdla $\mathrm{v}$ plece $\mathrm{v}$ podobě esovitého prohnutí a vejčitě klenuté tělo, $\mathrm{v}$ několika př́ípadech se setkáváme s ostrým lomem mezi hrdlem a plecí (tab. 3:1, 9; tab. 5:9). Mezi keramické nálezy lze zařadit i dvojici přeslenů modelovaných z hlíny. Jeden z nich o průměru těla $25 \mathrm{~mm}$ a otvoru $9 \mathrm{~mm}$ měl fasetované hrany a byl nalezen v sondě 5 ve vrstvě 5002 (tab. 4:19).

Okraje hrnců $(\mathrm{H})$ byly rozděleny podle profilace a morfologie vlastního okraje do celkem 12 skupin. U okrajů mís (M) byly určeny tři skupiny. Typologické schéma okrajů ukazuje obr. 8. Průměr okrajů se pohyboval v intervalu od 10 do $28 \mathrm{~cm}$, největší zastoupení měly okraje střední hodnoty mediánu od 14 do $26 \mathrm{~cm}$. Největší zastoupení měly okraje hrnců s mírně vytaženou spodní a horní hranou, na horní ploše okraje mírně prožlabené ( $46 \%$, skupina H.9); dále okraje vně vyhnuté a šikmo seříznuté $(28 \%$, H.5). Tyto okraje se nejvíce vyskytovaly společně v sondách 5 a 8 (obr. 6). Ostatní skupiny a typy okrajů se pohybovaly jen v rozmezí $2-5 \%$ zastoupení. Pouze tři okraje náležely miskám s mírně zataženým nebo vodorovně vyloženým okrajem.

\subsubsection{Výzdoba}

Posledním hodnoceným znakem byl způsob provedení výzdoby. Také v případě výzdoby bylo přihlédnuto k publikovanému typáŕi výzdoby raně středověké keramiky z Hradce u Němětic (Michálek-Lutovský 2000, 219-221, obr. 80a-c).

Zdobeno bylo celkem 196 zlomků keramiky. Výzdoba byla nejčastěji umístěna na podhrdlí a výdutích nádob a byla provedena jednoduchým rydlem nebo vícehrotým nástrojem - hřebenem. Schéma nejčastěji zastoupených výzdobných motivů ukazuje obr. 9, kde písmeno R označuje skupinu ryté výzdoby a V výzdobu pomocí vpichů, vrypů a vseků. Dvoumístné číslo pak označuje typ a variantu výzdoby.

Výzdobné prvky byly posuzovány a popisovány na zlomkové keramice jako jednotliviny nebo složené motivy, tvořené kombinací více výzdobných prvků. Nejvíce byla zastoupena hřebenová vlnice provedená vícehrotým hřebenovým nástrojem (42\%), jednoduchá rytá vlnovka vytvořená jednozubým nástrojem byla zastoupena již výrazně méně $(8 \%)$. Objevovaly se pravidelné vysoké hřebenové vlnice bez sklonu (tab. 2:13), v několika př́ípadech se sklonem a výrazně zahrocené (tab. 1:9). Vícenásobná hřebenová vlnice bez sklonu či se sklonem byla doložena na tělech nádob i v několika pravidelných či víceméně pravidelných pásech, nejčastěji po dvou (tab. $1: 1,4,5,11,12$; tab. 2:4-6; tab. 3:3; tab. 4:17, 9, 15; tab. 5:2, 3-5, 8-9) nebo po třech pásech (tab. 3:5; tab. 4:4; tab. 5:1). Počet pásů doložených vlnic je však determinován velikostí fragmentu. Kromě hřebenových vlnic byly zastoupeny hřebenové rýhy (7\%, tab. 1:6-7).

$\mathrm{Z}$ dalších druhů výzdoby byly doloženy hřebenové šikmé nebo vstř́ícné vpichy pravidelně či nepravidelně kladené nebo umístěné v pásech (celkem 13\%, tab. 1:8, 13, tab. 2:8, tab. 3:2, 4, 7, $10,14-15$, tab. 4:16, tab 6:2,7-8). Celkem v šesti prŕípadech byly hřebenové vpichy doloženy na vnitřní straně okraje (tab. 6:1). Dále se ojediněle vyskytovaly vrypy a vseky (3\%) a také šikmé čočkovité vrypy a vseky (méně než $1 \%$ ).

Setkáváme se s kombinacemi více výzdobných motivů, např́ílad rytých rýh, provedených hřebenovým nástrojem, oddělujících jednu nebo dvě hřebenové vlnice (10\%, tab. 1:6-7; tab. 2:11; tab. 3:6, tab. 4:6), ojediněle hřebenové vlnice a jednoduché rýhy ryté jednozubým nástrojem (tab. 4:11). Minoritní výzdobu tvoří (méně než $1 \%$ ) kombinace vlnovek a rýh (tab. 2:10). Ojediněle se setkáváme s pásem hřebenových vpichů a hřebenové vlnice (2\%, tab. 1:12; tab. 3:1; tab. 4:5), hřebenových vpichů a hřebenových rýh (2\%) nebo s kombinací hřebenových vpichů, vlnice 
a rytých hřebenových rýh (1\%, tab. 4:10). Vzácně (méně než $1 \%)$ se objevuje výzdoba v podobě pásu vpichů mezi dvěma vlnovkami (tab. 1:3).

Vzácně se objevila i kombinace lišty a vstřícných vpichů (2\%, tab. 6:3-6) a kombinace plastické lišty, vpichů a hřebenové vlnice (tab. 4:17). Právě keramické zlomky nesoucí hřebenovou vlnici a hřebenové vpichy se nejčastěji vyskytovaly spolu v nejpočetnějších souborech v sondách 5 a 8 u vnější paty valu dřevohlinité hradby (obr. 7).

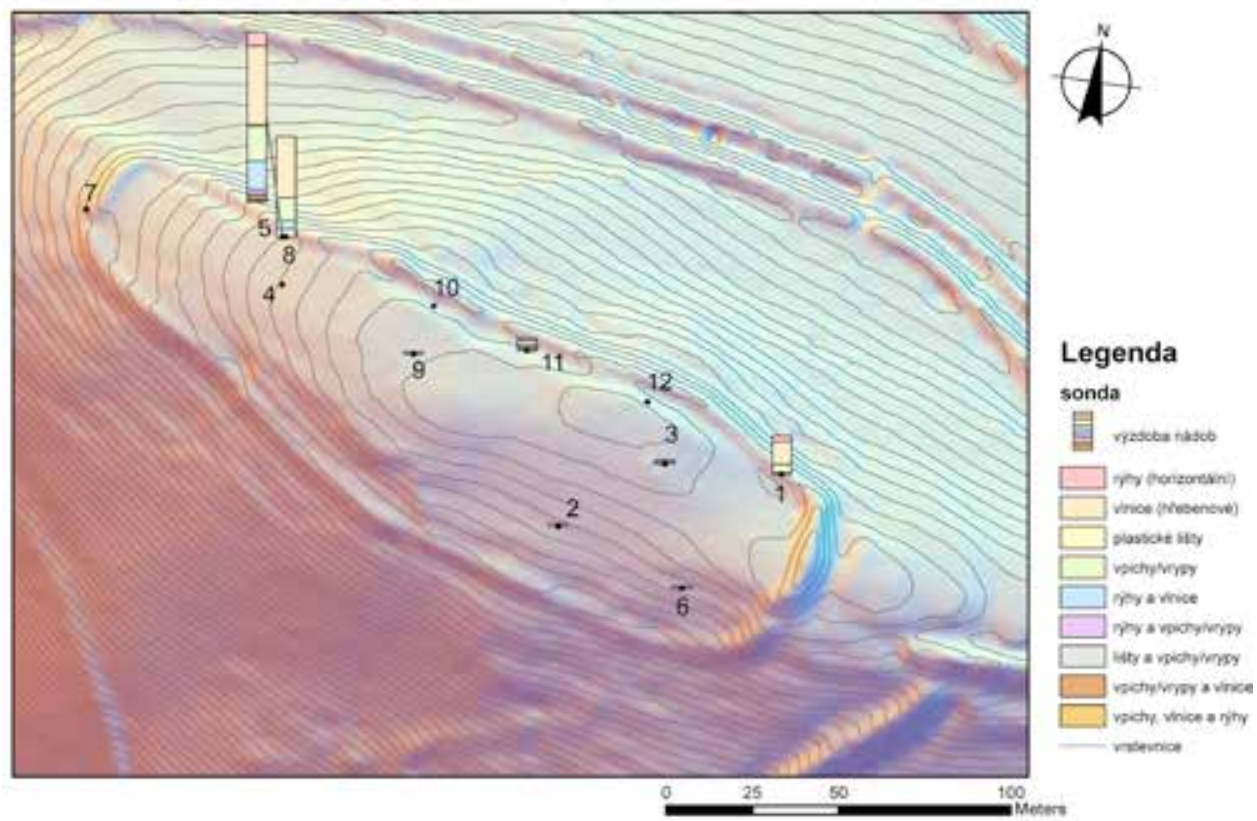

Obr. 7. Distribuce zdobených zlomků. Vytvořil L. Čapek.

Abb. 7. Verteilung der verzierten Fragmente. Erstellt von L. Čapek.

\section{Relativní datování a analogie}

Z jižních Čech sledovaného období postrádáme kvalitně zpracované stratifikované soubory raně středověké (středohradištní) keramiky či uzavřené nálezové celky (Lutovský 1993, 223; 1995). Datování středohradištní keramiky je jen relativní a opíráme se pouze o několik srovnávacích souborů z regionu. Jedny z mála opor relativního datování představují stratifikované soubory raně středověké keramiky z hradiště Hradec u Němětic z druhé třetiny 9. a počátku 10. století (Michálek-Lutovský 2000 214-222) a ke komparaci lze využít raně středověkou keramiku z hradiště v Liběticích získanou především z povrchových sběrů (Lutovský 1993, Taf. 6-8; Profantová 1997, 27-28, obr. 2-7; Lutovský-Michálek 1999, 61-62, Taf. 2). Podobné znaky nacházíme i na raně středověké (středohradištní) keramice ze vzdálenějšího hradiště u Kuklova na Českokrumlovsku datovaného s výhradami do období druhé poloviny 8. a první poloviny 9. století (Lutovský 1990, 83-87, obr. 3-7) a u kolekce souborů pocházejících z povrchových sběrů v okolí Písku, v povodí Blanice na Vodňansku a Protivínsku a v oblasti horního Pootaví obsahující i výraznou část keramiky z konce 8 . a počátku 10. století (Fröhlich-LutovskýParkman 2002, 121, obr. 4-9, 13-14; Fröhlich-Lutovský-Michálek 2004, 213-214, obr. 2-14; Eigner-Fröhlich-Lutovský 2009, obr. 4-8). Porovnáme-li soubory keramiky z katovického 

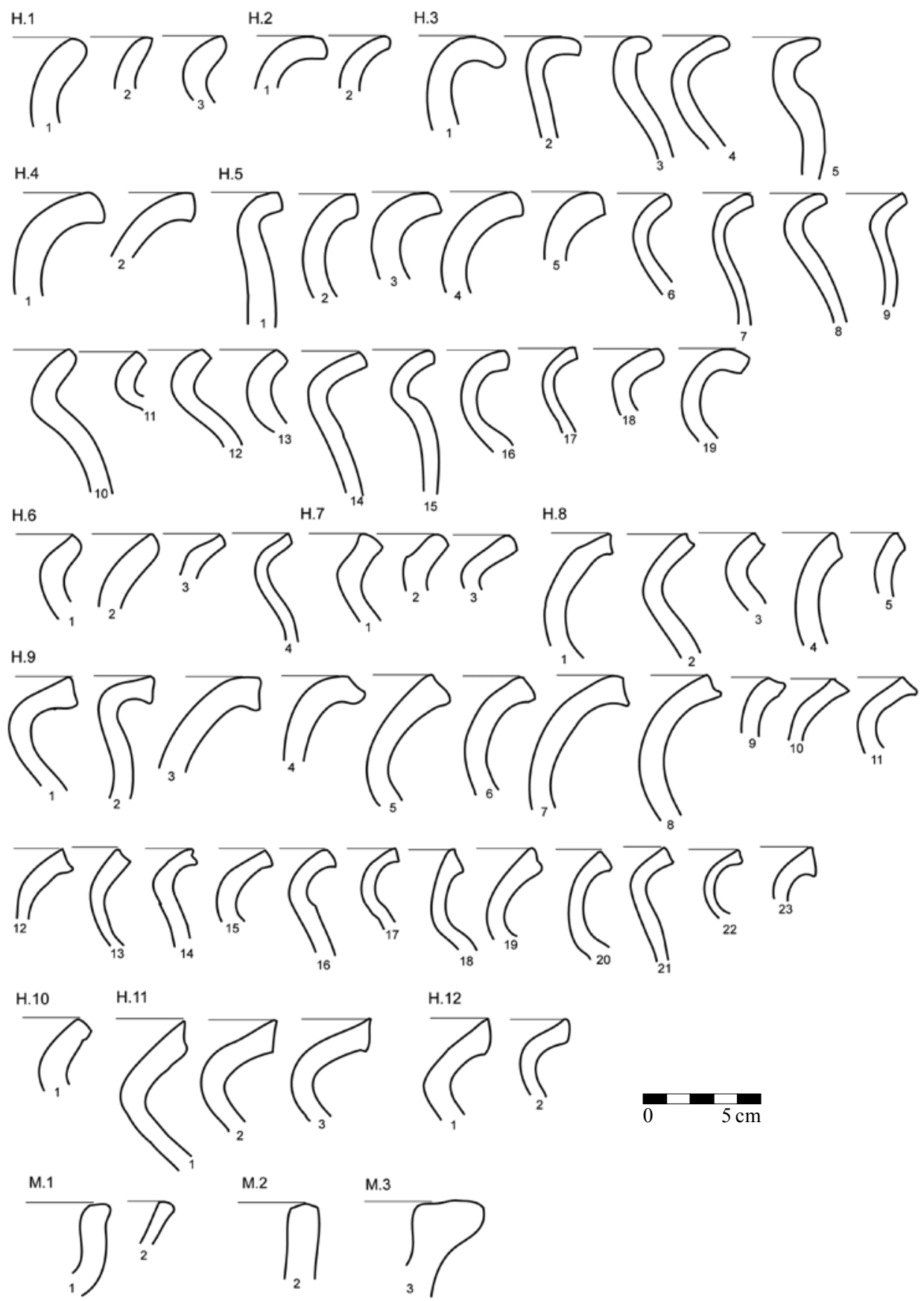

Obr. 8. Typář okrajů hrnců a mís. Vytvořil L. Čapek.

Abb. 8. Typenübersicht der Topf- und Schüsselränder. Zusammengestellt von L. Čapek. 


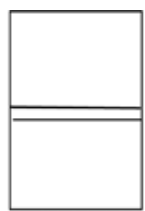

R.02.01

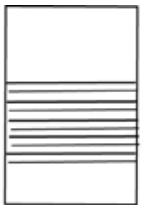

R.02.04

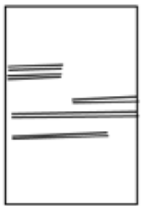

R.03.01

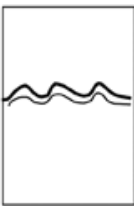

R.05.01
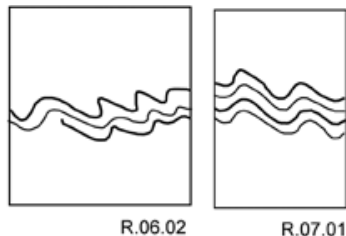

R.07.01
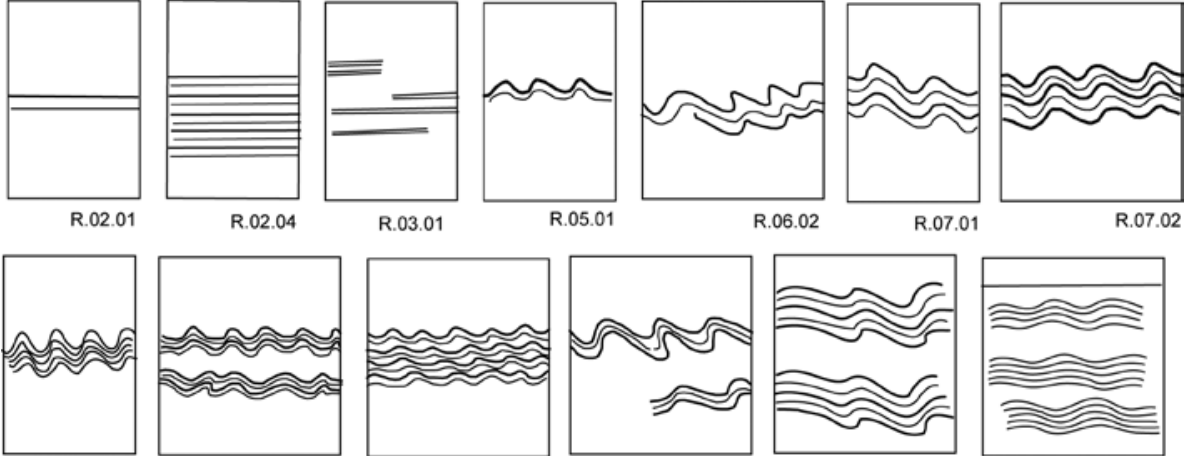

R.07.05
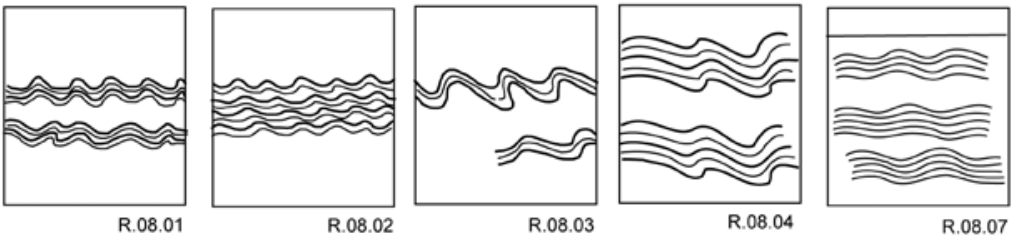
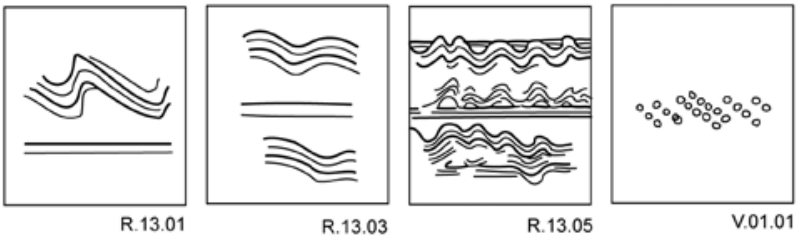

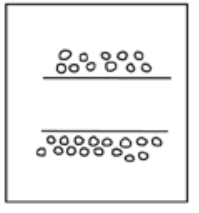

V.02.03

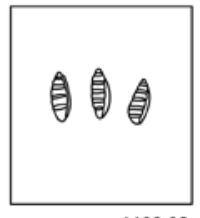

V.03.02

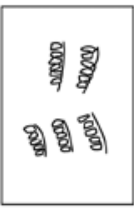

V.05.03

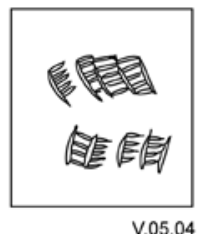

Obr. 9. Typář zdobených zlomků - nejčastěji zastoupené skupiny a typy výzdoby v souboru. Vytvořil L. Čapek.

Abb. 9. Typenübersicht der verzierten Fragmente - im Fundkomplex am häufigsten vertretene Verzierungsgruppen und -typen. Zusammengestellt von L. Čapek.

hradiště s keramikou z blízkých hradišt' Hradce u Němětic a Libětic, shledáme řadu společných znaků, co se týče morfologie okrajů a výzdobných motivů, jen s malými rozdíly. V př́ípadě raně středověké keramiky z Katovic se ve výrazné míře vyskytují okraje s mírně vytaženou spodní a horní hranou, oproti tomu na Hradci u Němětic je tato skupina okrajů č. III v menšině (Michálek-Lutovský 2000, 216). Řada šikmých hřebenových vpichů na vnitřní straně ústí okraje (tab. 6:1) je v Katovicích doložena víckrát (celkem 7×) než u němětického souboru, kde je doložen pouze jeden exempláŕ (Michálek-Lutovský 2000, Taf. 138:5). Okraj s hřebenovými vpichy na vnitřní straně okraje je doložen také v Liběticích (Lutovský 1993, Tab. 7:9). Naopak v souboru z Katovic není doloženo přesekávání okraje hřebenovými vrypy a vpichy, které jsou typické pro skupinu keramiky z Němětic (Michálek-Lutovský 2000, 221-222, Taf. 82). Více se také v Katovicích setkáváme s plastickými hraněnými lištami, někdy přesekávanými vrypy či vseky, které doprovází pásy hřebenového vpichu a vzácně vlnice nad a pod lištou. Tyto výzdobné motivy pocházejí z jedné nebo více nádob (tab. 6:3-6), které byly nalezeny v největším zastoupení v sondě 8 . Podobné tvary lišt na středohradištní keramice z jižních Čech nebyly zaznamenány. S plastickými lištami se setkáváme v jižních Čechách u keramiky z počátku mladohradištního období, přibližně od poloviny 10 . století. Plastické lišty špičatých a hraněných tvarů jsou doloženy v souborech keramiky z hradiště Kozárovice, jsou datované do sklonku 10. a zejména do 11. století, kdy však lišty častěji vystupují v kombinaci s jednoduchými nebo ještě vícenásobnými vlnicemi a jen ojediněle s hřebenovými vpichy (Buchvaldek-Sláma-Zeman 1978, 80, obr. $21: 5,28: 8)$. Oblé a ploché plastické lišty jsou doloženy i u raně středověké keramiky z Chýnova 


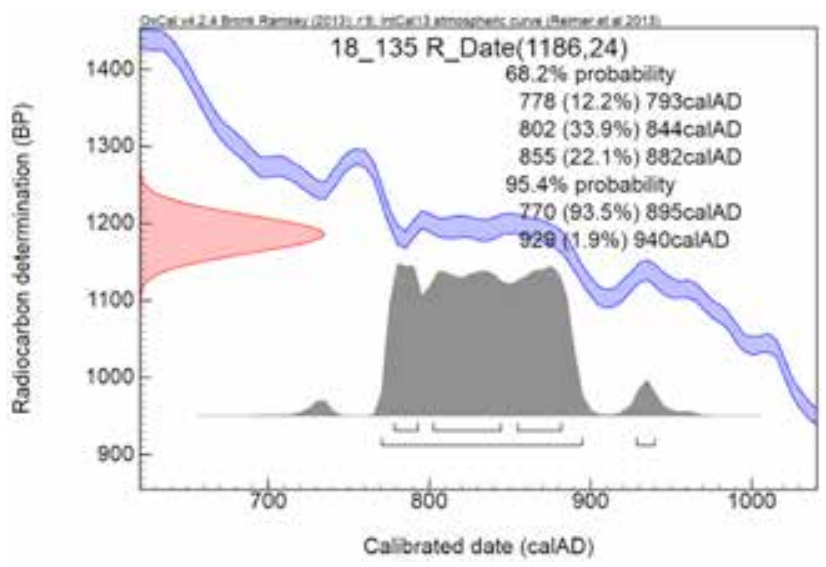

Obr. 10. Výsledky radiokarbonové analýzy - vzorek 18_135. Zpracoval I. Světlík. Abb. 10. Ergebnisse der Radiokarbonanalyse - Probe 18_135. Aufbereitung I. Světlík.

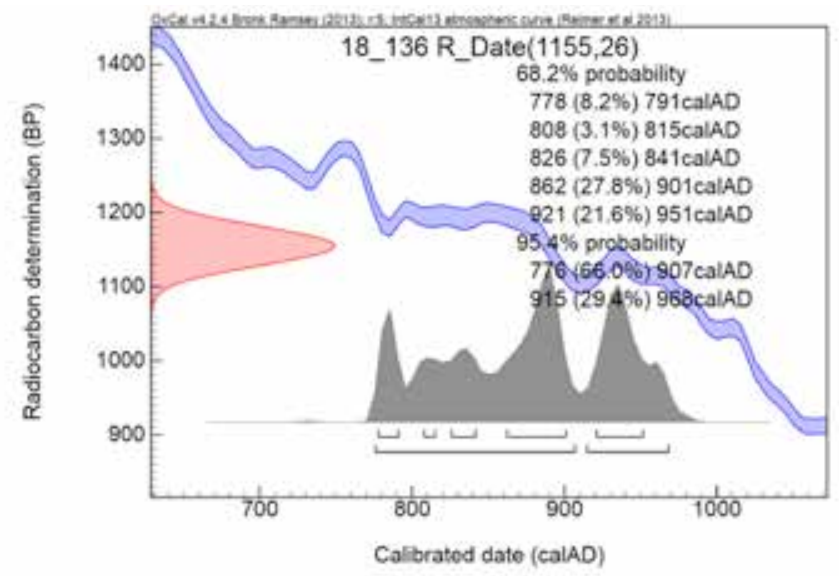

Obr. 11. Výsledky radiokarbonové analýzy - vzorek 18_136. Zpracoval I. Světlík. Abb. 11. Ergebnisse der Radiokarbonanalyse - Probe 18_136. Aufbereitung I. Světlík.

datované do 11. a 12. století a některé z nich ještě nesou výzdobu hřebenových vpichů a vrypů (Krajíc 2010, 178, obr. 27).

Jistým chronologickým ukazatelem je i výrazná absence grafitové keramiky. Velmi malou přítomnost grafitu v keramické hmotě registroval již u starších nálezů keramiky z hradiště v Katovicích B. Dubský (Dubský 1949, 669-670). Také z blízkého Hradce u Němětic pochází pouze dva zlomky grafitové keramiky (Michálek-Lutovský 2000, 216) a z hradiště Libětice jeden zlomek (Lutovský-Michálek 1999, 62). S grafitovou keramikou se v jižních Čechách setkáváme výrazněji až s nástupem mladší doby hradištní v pokročilém 10. století, pomineme-li některé nejstarší ojedinělé nálezy grafitové keramiky především ze středohradištních mohylových pohřebišt' a sporadický výskyt zaznamenaný na některých jihočeských hradištích již ve druhé polovině 9. století (Lutovský 1993, 227-228; 1995, 224-225; Thomová 1998, 213-215; Michálek-Lutovský 2000, 214).

Přitom okolí hradiště patři do oblasti moldanubika (pestré série sušicko-votické) s ložisky krystalických (vločkových) a mikrokrystalických grafitů, které se nacházejí ve výchozech přímo 
v zázemí hradiště na svazích nad řekou Otavou. Zdejší ložiska grafitu byla těžena v mladších historických obdobích (Kratochvíl-Rost 2000, 243-249). Blízká dostupnost grafitu zřejmě neovlivnila charakter místní produkce keramiky.

Určité shody ve způsobu profilace okrajů (jednoduché zaoblené nebo šikmo seříznuté okraje bez prožlabení) a provedení výzdoby (hřebenová vlnice, hřebenové rýhy) shledáváme i u jiných souborů středohradištní keramiky z 9. a počátku 10. století ze vzdálenějších regionů (stř̌ední a severozápadní Čechy). Jedná se např́klad o nejstarší soubory keramiky z horizontů PH A0 až PH A1 před výstavbou dřevohlinité hradby Pražského hradu, datované dendrodaty ante quem 908-917 (Boháčová 2001, 270-273, obr. 33). K dalšímu srovnání můžeme použít i soubory středohradištní keramiky z hradiště v Libici nad Cidlinou, kde je zastoupena keramika s hřebenovými vpichy až do první poloviny 10. století (Princová-Justová 1994, 194, 198-200, Abb. 2-3). Také v severozápadních Čechách (keramický okruh Rubín - Žatec) se keramika s hřebenovými vpichy a hřebenovými vlnicemi objevuje do první poloviny 10. století (Bubeník-Meduna 1994, 190-191, Abb. 2, 4).

Raně středověkou keramiku z hradiště Kněží hora můžeme relativně datovat do středohradištního období, rámcově do průběhu 9. až přelomu 9. a 10. století na základě srovnání s publikovanými soubory středohradištní keramiky z jižních Čech (zejména z Hradce u Němětic). $Z$ dřevěné hradby roštové konstrukce odkryté během archeologického výzkumu byly odebrány dva vzorky na radiokarbonové datování (Světlík 2018). Kalibrovaná data ukazují na interval datování výstavby hradby mezi lety 770-895 a 776-968 AD (obr. 10 a 11). ${ }^{2}$ Bohužel z konstrukce hradby nepochází žádné keramické zlomky. V keramickém souboru jsme prozatím neidentifikovali prvky staršího období z 8. století ani výraznější progresivnější prvky ukazující na druhou polovinu 10. století. Většina nálezů středohradištní keramiky z hradiště v Katovicích odpovídá dataci zániku hradišt' ve středním Pootaví, předpokládaného na počátku 10. století a prokázaného nejlépe u němětického hradiště (Lutovský 2011, 206-213). Nicméně se v keramickém souboru objevují některé prvky, které jsou později typičtější pro mladohradištní keramiku - okraje s vytaženou spodní a horní hranou, výzdoba jednozubým nástrojem (vlnovky, rýhy), dále vrypy, lišty a u hrncovitých nádob odsazení pod hrdlem. Nelze vyloučit i přežívání některých motivů dále do mladohradištního období. Např́íklad na části starší mladohradištní keramiky ze sídliště ve Vodňanech se ještě do druhé poloviny 12. století můžeme ojediněle setkat s hřebenovými vpichy, hřebenovou vlnicí a pásy hřebenových rýh, které zde vystupují společně s vrypy, vlnovkami a rýhami (Michálek 1983, obr. 12:2-3; 1986, 32-35, obr. 30:4, 6, 10, 11; obr. 32:12; obr. 33:9-13). Na základě hodnocení keramiky lze připustit i pokračování osídlení na katovickém hradišti $\mathrm{v}$ průběhu 10. století, byt' v redukované podobě.

\section{Závěr}

Z hradiště Kněží hora byl získán početný soubor raně středověké keramiky, jejíž podrobný rozbor přispívá k datování doby existence hradiště a v obecné rovině i ke stavu poznání jihočeské raně střredověké (stř̌edohradištní) keramiky. Hodnotné soubory pocházely zejména ze sond položených u paty vnitřního valu akropole (sonda 1,5 a 8). Keramika vykazuje technologické a morfologické znaky a výzdobné prvky typické pro stř̌edohradištní období 9. století (jednoduše profilované okraje, hřebenové vlnice, hřebenové vpichy), kterým neodporují ani nálezy kalibrovaných radiokarbonových dat z konstrukce hradby. Systematický výzkum z let 2016 a 2017 a rozbor středohradištní keramiky nepřinesl doklady pro počátky staršího osídlení, v literatuře kladené již do 8. století, a to na základě jediného náhodně nalezeného střepu s kazetovým motivem a zdobeného kolkem (!) publikovaného B. Dubským (Dubský 1949, 594, obr. 29:14), který je v literatuře kladen i do období stěhování národů (Zavřel 1999, 484, tab. 13). Keramika s kolky

2 Kalibrační diagramy (křivka průběhu hustot pravděpodobnosti je přidružena k vodorovné ose diagramu) spolu s podrobným výpisem intervalů kalibrovaného stáŕi pro hladiny pravděpodobností $95 \%$ a $68 \%$ a skupinový diagram porovnání křivek hustoty pravděpodobnosti období původu jednotlivých vzorků. Aktivity C14 obou vzorků se statisticky významně neliší, lze proto předpokládat jejich původ ve stejném období (Světlík 2018; vzorky 18_135, 18_136; kalibrováno OxCal-v.4.3.2). 
obdobného provedení se na starší slovanské keramice vyskytuje od 6. do 8. století (Profantová, 2016, 130, obr. 6:1-3; Kuna-Profantová a kol. 2005, 174-175). Motiv kolku kruhového tvaru se sporadicky objevuje ještě v 9. století v jižních Čechách (Lutovský 1990, 82, obr. 2:7). Naopak se ukazuje, že těžiště většiny keramických nálezů spadá do období 9. století. Jen ojediněle zaznamenáváme na keramice prvky, které jsou typičtější pro mladší dobu hradištní (vlnovky, jednoduché ryté rýhy, okraje s vytaženou horní a spodní hranou). Horní chronologickou hranici prozatím nelze stanovit blíže než do průběhu 10. století na základě komparace s raně středověkou keramikou z archeologického výzkumu hradiště Hradec u Němětic a dalších středohradištních až mladohradištních jihočeských lokalit. Jistým datovacím ukazatelem je absence grafitové keramiky, k jejímuž většímu rozšíření dochází až po polovině 10. století (Lutovský 1993, 227-228; 1995, 224-225; Thomová 1998, 213-215).
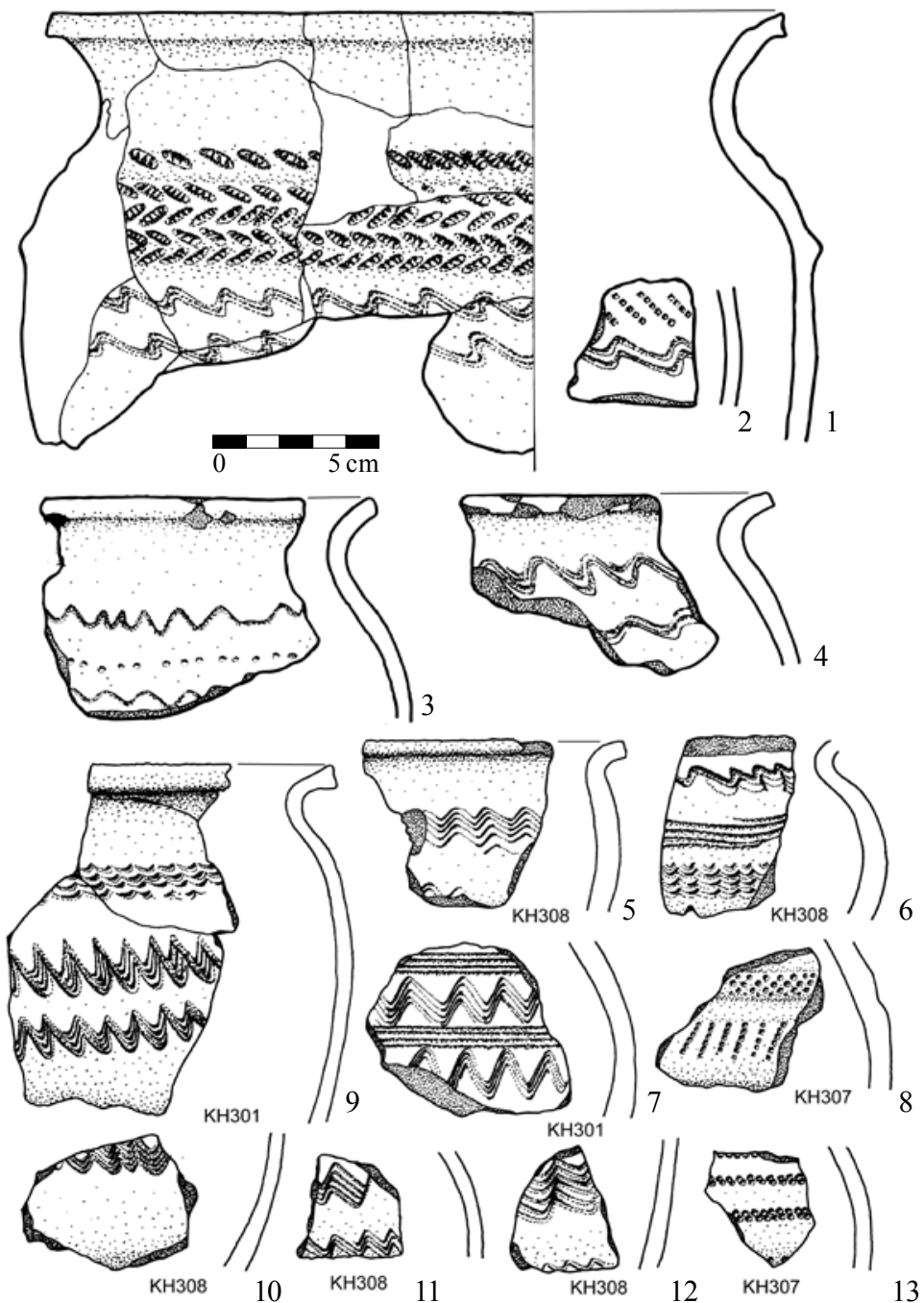

Tab. 1. Výběrová dokumentace raně středověké (středohradištní) keramiky z výzkumu B. Dubského v roce 1946 (1-8) a povrchových sběrů z 80. let 20. století (9-13). Kresba H. Hrubá.

Taf. 1. Auswahldokumentation frühmittelalterlicher (mittelburgwallzeitlicher) Keramik von B. Dubskýs Grabung aus dem Jahr 1946 (1-8) und den Oberflächensammlungen aus den achtziger Jahren des 20. Jahrhunderts (9-13). Zeichnung H. Hrubá. 

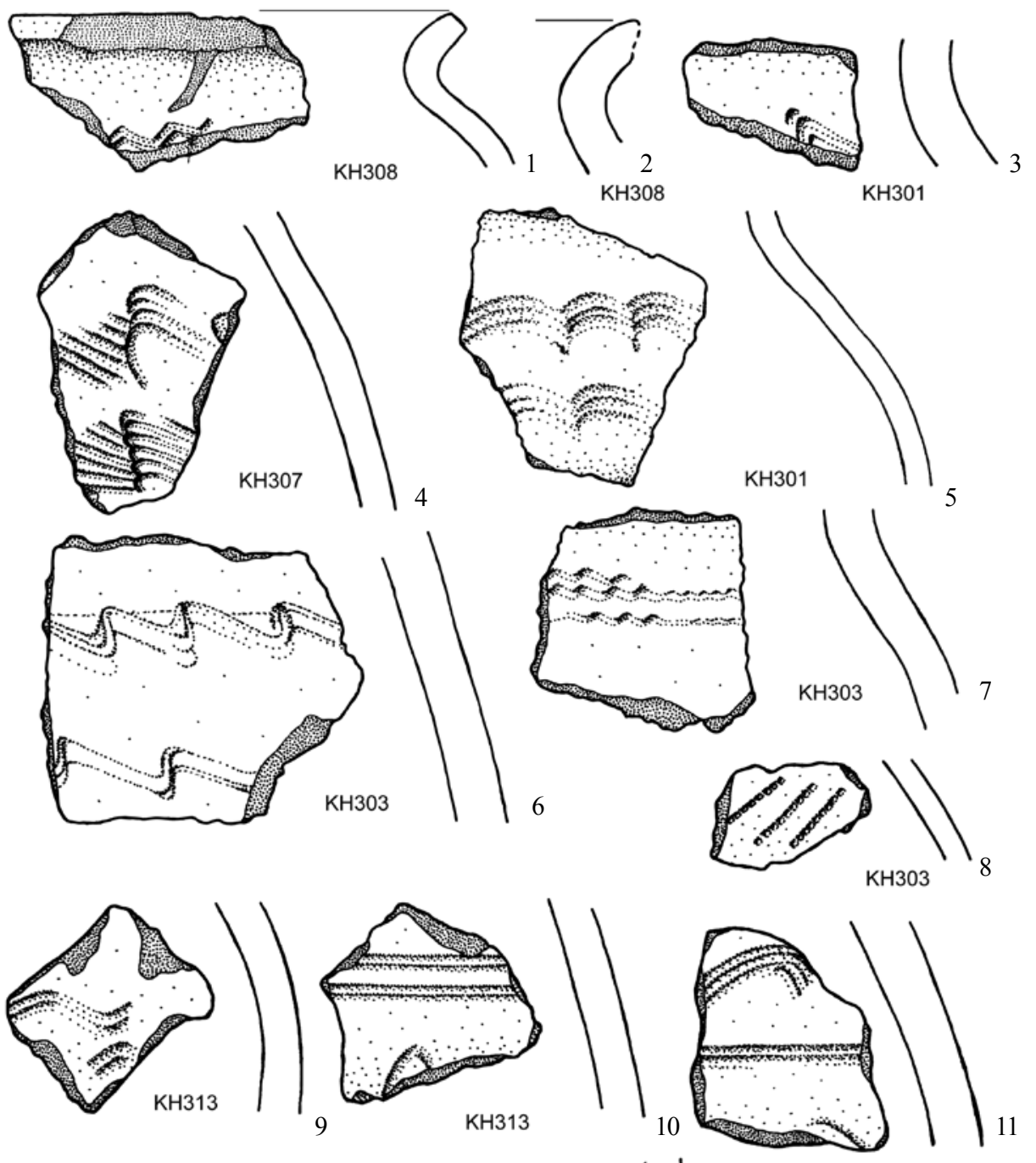

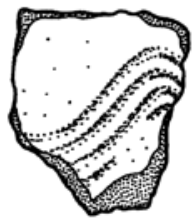

$\mathrm{KH} 301$

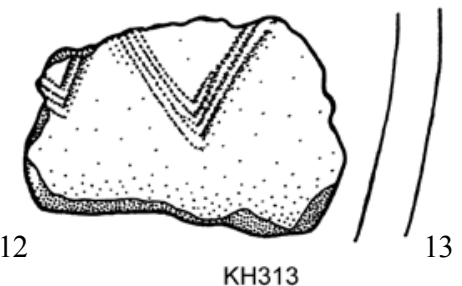

$\mathrm{KH} 313$
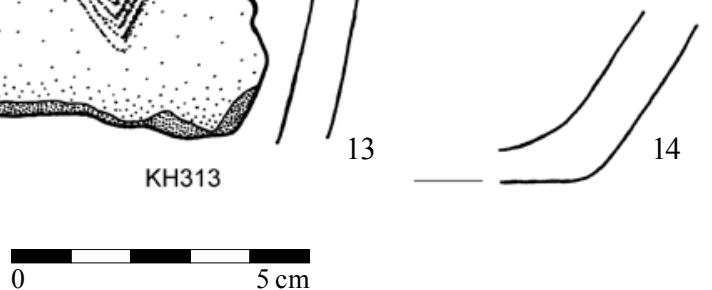

Tab. 2. Výběrová dokumentace raně stř̌edověké (stř̌edohradištní) keramiky ze sondy 1 - SJ 1002. Kresba H. Hrubá.

Taf. 2. Auswahldokumentation frühmittelalterlicher (mittelburgwallzeitlicher) Keramik von Sondierschnitt 1 - SJ 1002. Zeichnung H. Hrubá. 

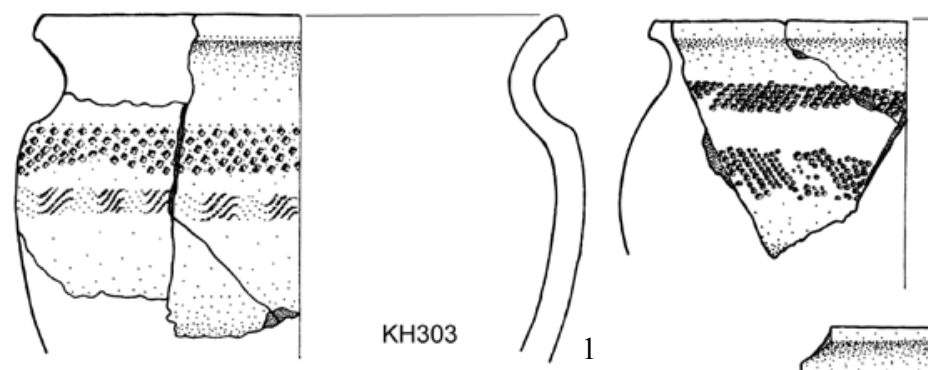

$\mathrm{KH} 303$
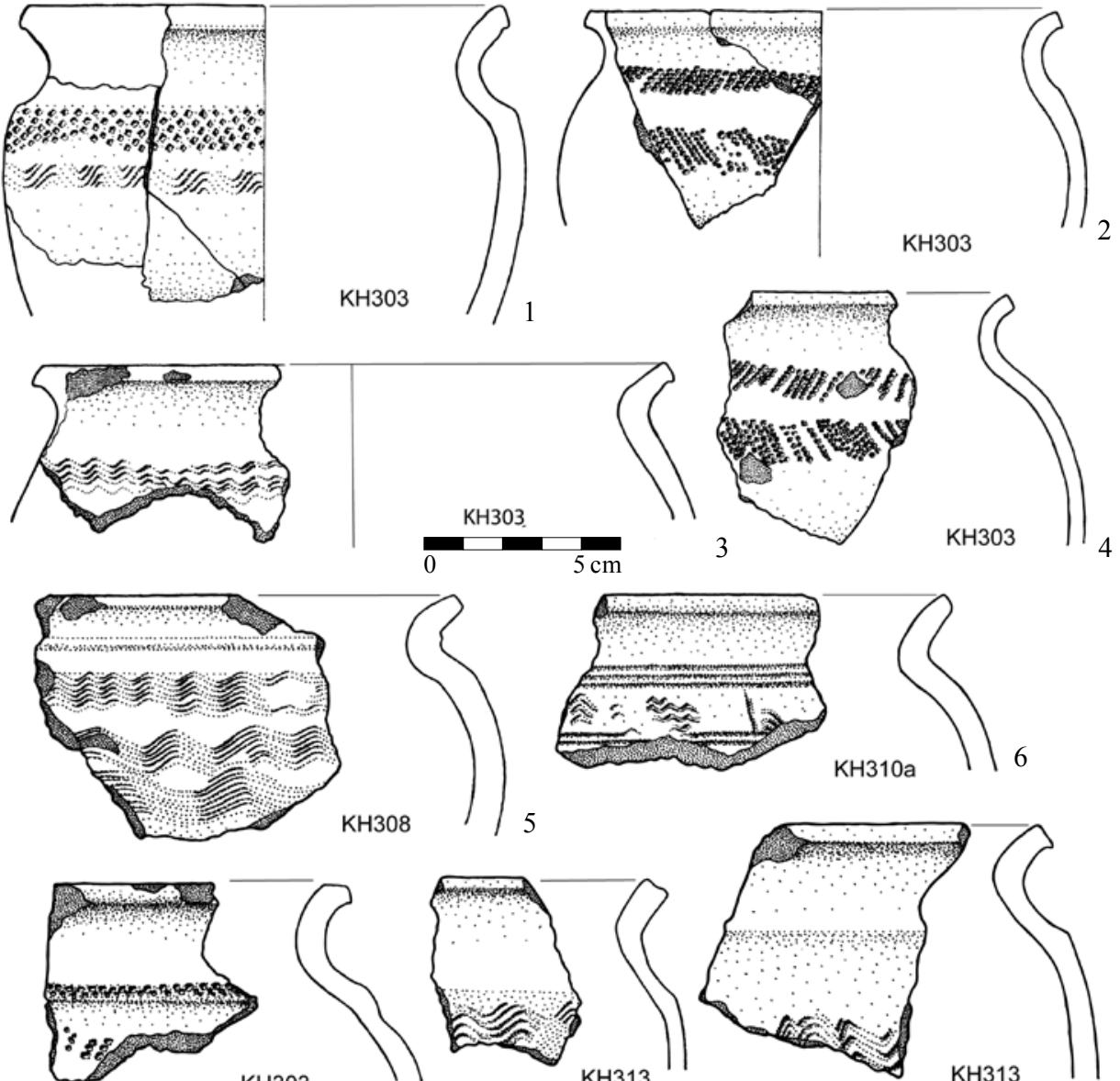

$\mathrm{KH} 303$
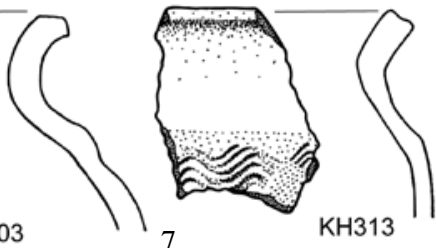

7

$\mathrm{KH} 313$

8
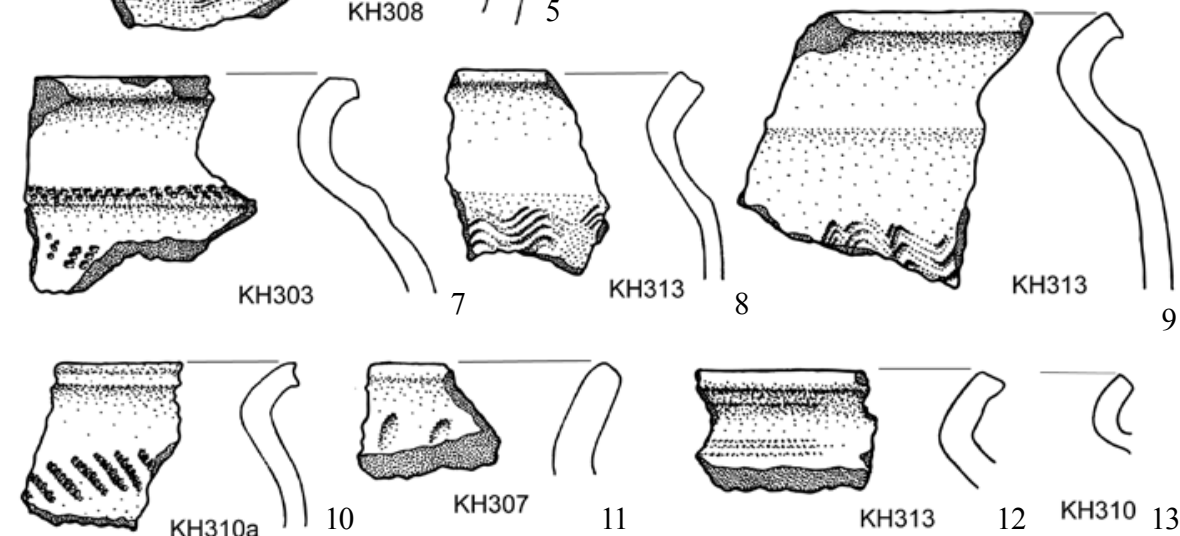

$\mathrm{KH} 307$

11
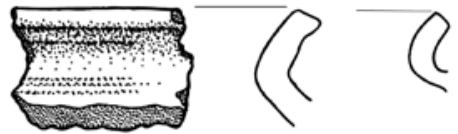

$\mathrm{KH} 313$

12

KH310 13
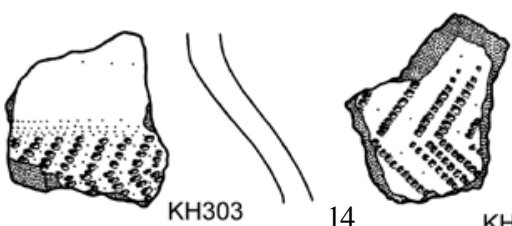

14

$\mathrm{KH} 307$
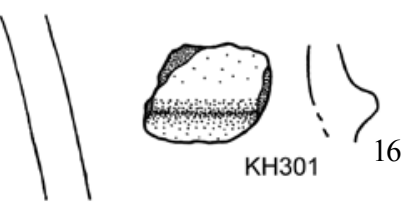

15

Tab. 3. Výběrová dokumentace raně stř̌edověké (středohradištní) keramiky ze sondy 5 - SJ 5002. Kresba H. Hrubá.

Taf. 3. Auswahldokumentation frühmittelalterlicher (mittelburgwallzeitlicher) Keramik von Sondierschnitt 5 - SJ 5002. Zeichnung H. Hrubá. 

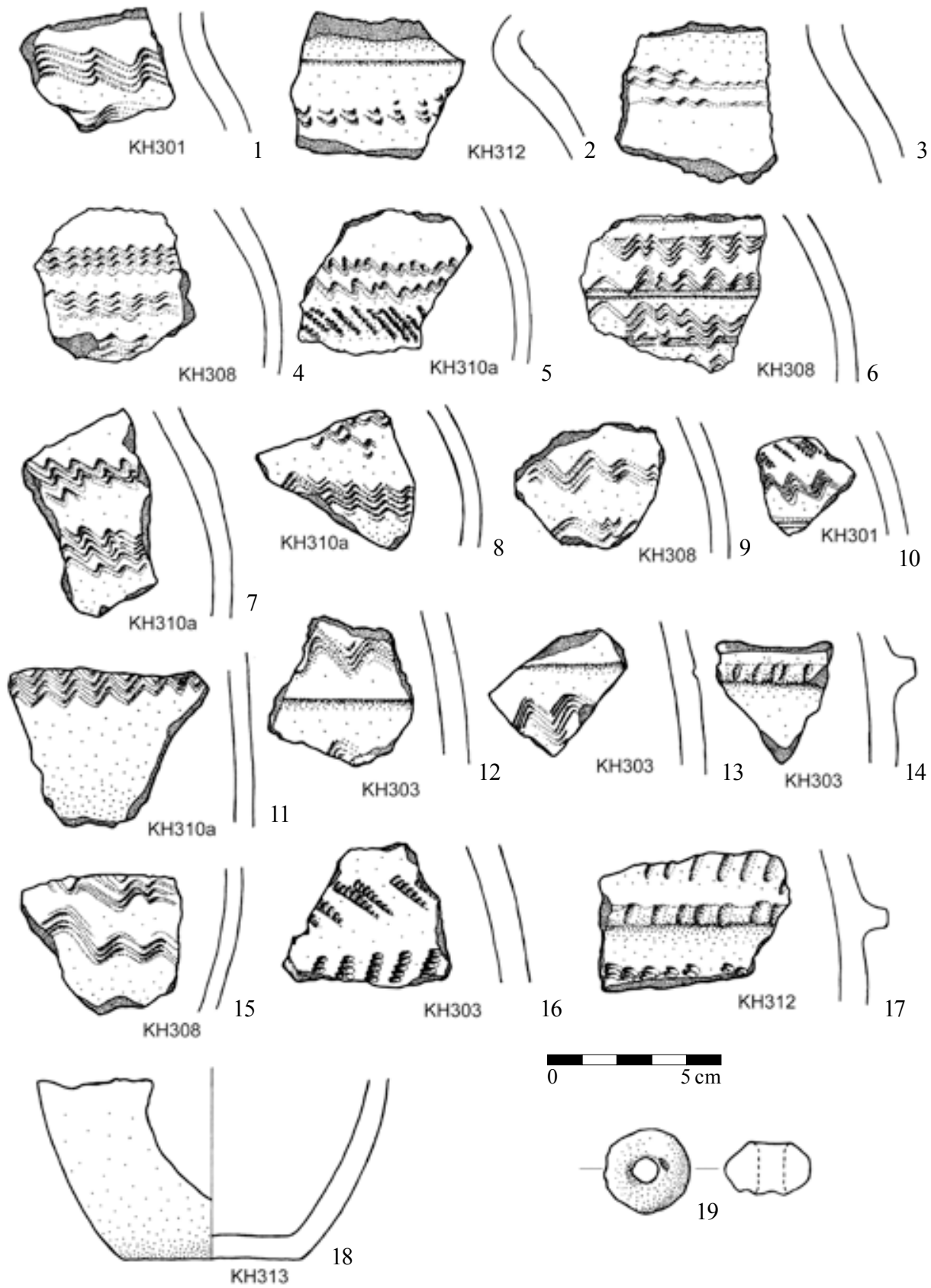

Tab. 4. Výběrová dokumentace raně stř̌edověké (stř̌edohradištní) keramiky ze sondy 5 - SJ 5002. Kresba H. Hrubá.

Taf. 4. Auswahldokumentation frühmittelalterlicher (mittelburgwallzeitlicher) Keramik von Sondierschnitt 5 - SJ 5002. Zeichnung H. Hrubá. 

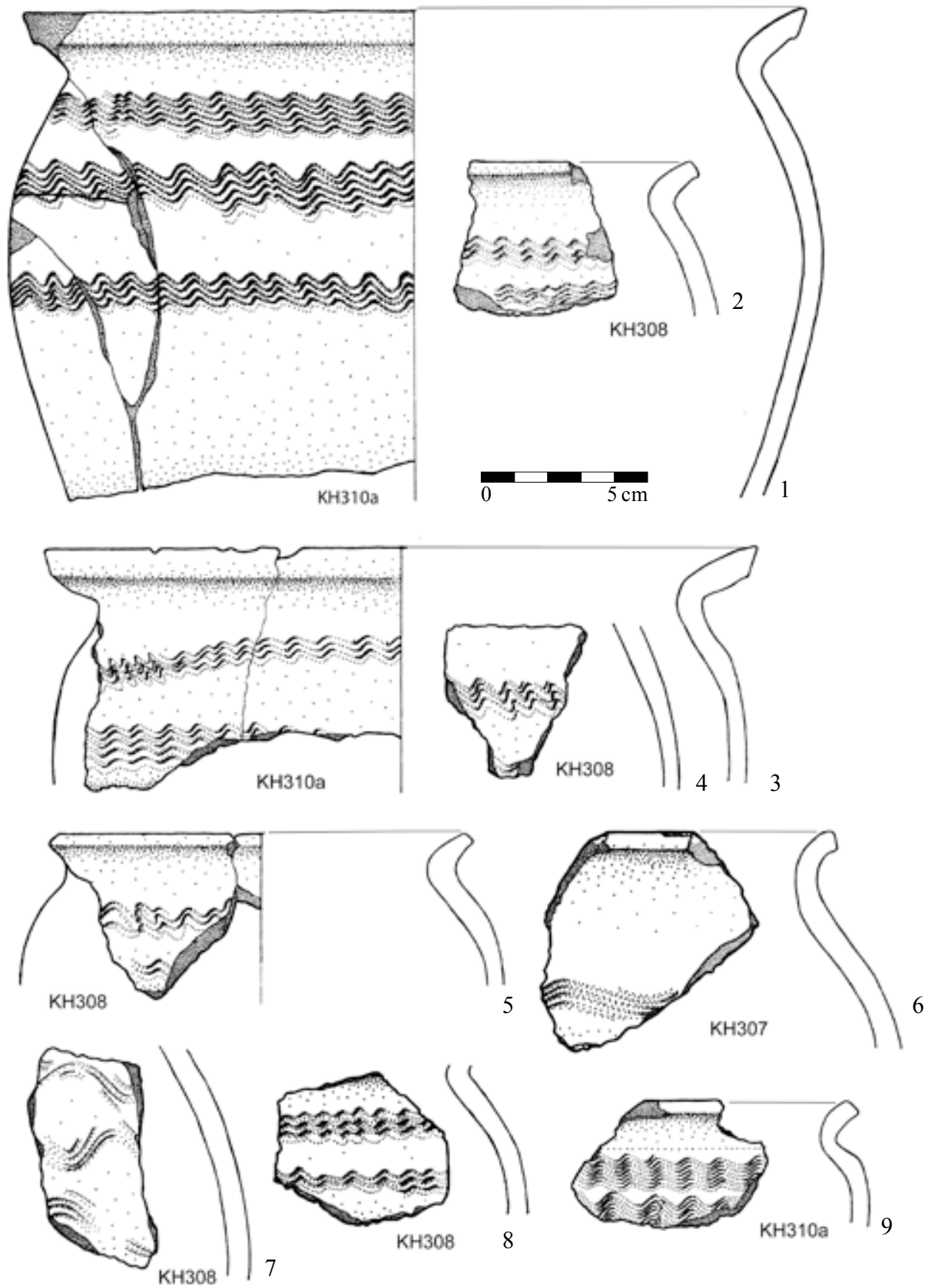

Tab. 5. Výběrová dokumentace raně stř̌edověké (stř̌edohradištní) keramiky ze sondy 8 -SJ 8002. Kresba H. Hrubá.

Taf. 5. Auswahldokumentation frühmittelalterlicher (mittelburgwallzeitlicher) Keramik von Sondierschnitt 8 - SJ 8002. Zeichnung H. Hrubá. 

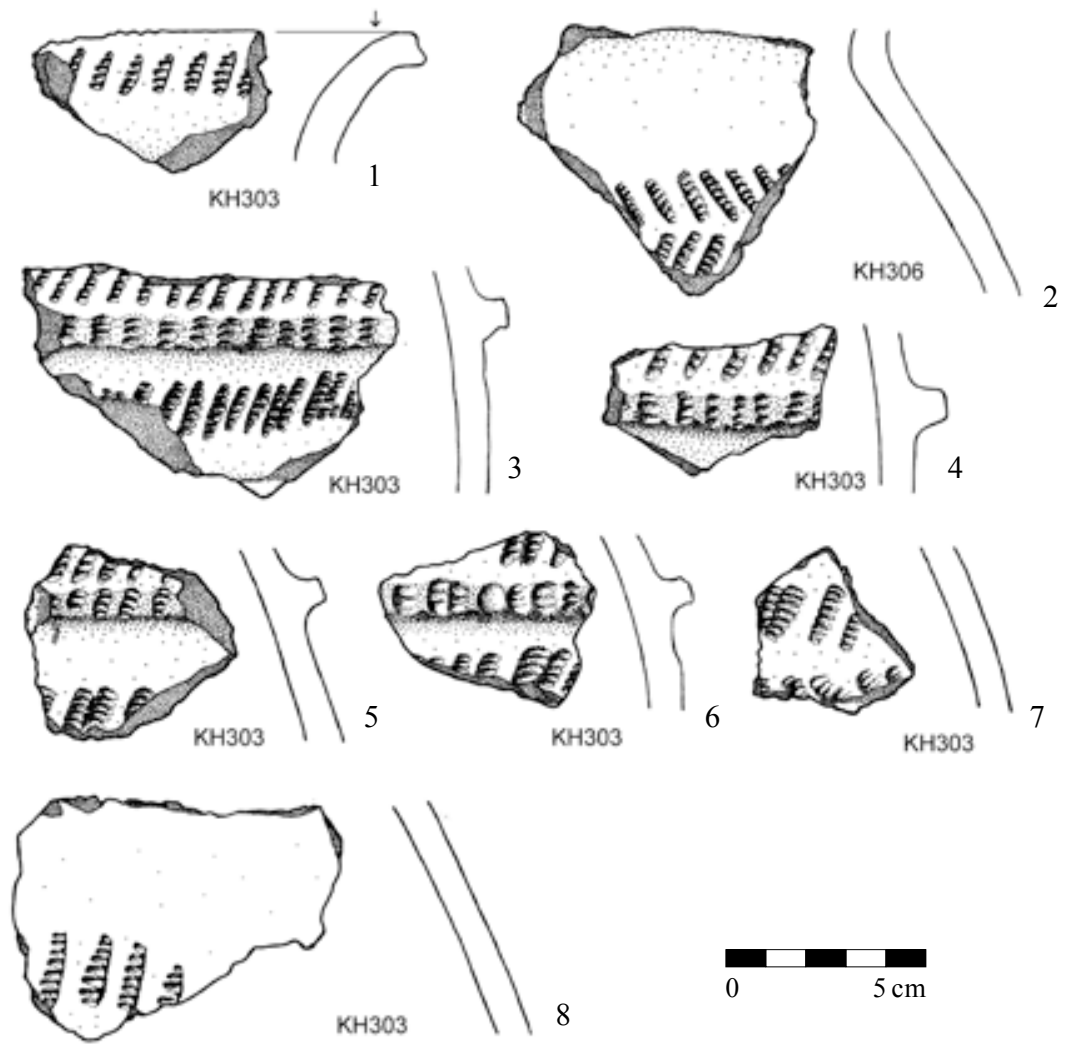

\section{8}

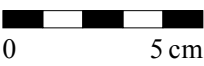

Tab. 6. Výběrová dokumentace raně středověké (středohradištní) keramiky ze sondy 8 - SJ 8002. Kresba H. Hrubá. Taf. 6. Auswahldokumentation frühmittelalterlicher (mittelburgwallzeitlicher) Keramik von Sondierschnitt 8 - SJ 8002. Zeichnung H. Hrubá.

\section{Soupis keramických trííd ${ }^{3}$}

\section{KH301}

Zrnitost: hrubozrnná (1,5-2,5 mm); příměsi (ostřivo): četně zrna písku (do $2 \mathrm{~mm}$ ) a dalších hornin vystupující místy na povrch; výpal: středně tvrdý oxidační; úprava povrchu: vnější a vnitřní povrch hrubý; barva: barva vnějšího povrchu okrovohnědá, barva na lomu šedohnědá, barva vnitřního povrchu šedá.

\section{KH303}

Zrnitost: středozrnná (0,1-1,5 mm); příměsi (ostřivo): místy zrnka písku (do $1 \mathrm{~mm}$ ), četně příměs stříbřité a zlatavé slídy; výpal: středně tvrdý oxidační; úprava povrchu: vnější a vnitřní povrch jemně drsný; barva: barva vnějšího povrchu okrovohnědá, místy načervenalá, barva na lomu světle hnědá, barva vnitřního povrchu tmavě šedá až černá.

3 Do soupisu keramických tříd jsou zahrnuty třídy, které jsou popisovány v textu, a tř́ídy, které jsou uvedeny v obrazových př́lohách. Podrobný soupis všech keramických tříd včetně jejich obrazové dokumentace bude zveřejněn v samostatné publikaci. 


\section{KH306}

Zrnitost: stř̌edozrnná (0,5-1,5 mm); prŕíměsi (ostřivo): místy zrnka písku (do $1 \mathrm{~mm}$ ) vystupující na vnějším a vnitřním povrchu; výpal: tvrdý oxidační; úprava povrchu: vnější a vnitřní povrch jemně drsný; barva: barva vnějšího povrchu světle hnědá, barva na lomu šedohnědá, barva vnitřního povrchu šedá.

\section{KH307}

Zrnitost: středozrnná ( $0,5-1,5 \mathrm{~mm})$; příměsi (ostřivo): jen ojediněle zrnka písku (do $1 \mathrm{~mm}$ ), hojně příměs hrubě drcené stříbřité slídy; výpal: středně tvrdý oxidační výpal; úprava povrchu: vnější povrch hladký, vnitřní povrch jemně drsný; barva: barva vnějšího povrchu středně hnědá, barva na lomu tmavě šedá až černá, barva vnitřního povrchu tmavě šedá až černá; afinita: podobnost s tř́ídou KH308, liší se v množství a hrubosti stříbřité slídy.

\section{KH308}

Zrnitost: jemnozrnná (0,1-0,5 mm); př́iměsi (ostřivo): jen ojediněle zrnka písku, jemně drcená zlatavá slída; výpal: středně tvrdý oxidační, černé jádro; úprava povrchu: vnější povrch hladký, vnitřní povrch jemně drsný; barva: barva vnějšího povrchu šedohnědá, barva na lomu černá, barva vnitřního povrchu tmavě šedá až černá.

\section{KH310a}

Zrnitost: středozrnná (0,5-1,5 mm); příměsi (ostřivo): místy zrnka písku a hornin (kolem $1 \mathrm{~mm}$ ), vystupující četně na vnějším a vnitřním povrchu; výpal: středně tvrdý oxidační; úprava povrchu: vnější povrch hladký, vnitřní povrch jemně drsný; barva: barva vnějšího povrchu světle hnědá až nažloutlá, barva na lomu černá, barva vnějšího povrchu tmavě šedá.

\section{KH312}

Zrnitost: středozrnná (0,5-1,5 mm); příměsi (ostřivo): místy zrnka písku, četně příměs stříbřité slídy; výpal: střredně tvrdý oxidační; úprava povrchu: vnější povrch a vnitřní povrch jemně drsný; barva: barva vnějšího povrchu světle hnědá, barva na lomu světle hnědá, barva vnitřního povrchu tmavě šedá.

\section{KH313}

Zrnitost: středozrnná $(0,5-1,5 \mathrm{~mm})$; príměsi (ostřivo): četně zrnka hornin ojediněle vystupující na povrch, hojně prríměs stříbřité slídy; výpal: středně tvrdý oxidačně-redukční?; úprava povrchu: vnější a vnitřní povrch jemně drsný; barva: barva vnějšího povrchu černá, barva na lomu tmavě hnědočerná, barva vnitřního povrchu tmavě hnědočerná.

Článek byl podpořen projekty SGS-2018-010: Hradiště „Kněží Hora“ u Katovic, okr. Strakonice. Výpovědní potenciál lokality na základě multidisciplinárního výzkumu a NAKI II DG18P02OVV020: Vrcholně středověká keramika jako součást movitého kulturního dědictví. 


\section{Literatura}

BENEŠ, A., 1970: Katovice v pravěku. Pevnost na Kněží hoře. In: A věky jdou. Minulost a přítomnost jihočeského městečka Katovic a okolí (Kolář, E., ed.), 223-226. Katovice.

BOHÁČOVÁ, I., 2001: Pražský hrad a jeho nejstarší fortifikační systémy - Die Prager Burg und ihre ältesten Befestigungssysteme. In: Mediaevalia archaeologica 3 (Ježek, M.-Klápště, J., edd.), 179-301. Praha.

BUBENÍK, J.-MEDUNA, P., 1994: Zur frühmittelalterlichen Keramik in Nord-West-Böhmen. In: Slawische Keramik in Mitteleuropa vom 8. bis zum 11. Jahrhundert, Internationale Tagungen in Mikulčice I (Staňa, Č., ed.), 183-192. Brno.

BUCHVALDEK, M.-SLÁMA, J.-ZEMAN, J., 1978: Slovanské hradiště u Kozárovic. Praehistorica VI. Praha.

DUBSKÝ, B., 1928: Slovanský kmen na střední Otavě. Řepice.

- 1949: Pravěk jižních Čech. Blatná.

EIGNER, J.-FRÖHLICH, J.-LUTOVSKÝ, M., 2009: Nové doklady raně stř̌edověkého osídlení Horního Pootaví, ASČ 13, 881-893.

FRÖHLICH, J., 1990: Archeologické toulky po jižních Čechách. České Budějovice.

FRÖHLICH, J.-LUTOVSKÝ, M.-MICHÁLEK, M., 2004: Raně středověké osídlení v povodí Blanice na Vodňansku a Protivínsku - Die frühmittelalterliche Besiedlung entlang der Blanice im Raum von Vodňany und Protivín, AVJČ 17, 207-230.

FRÖHLICH, J.-LUTOVSKÝ, M.-PARKMAN, M., 2002: Raně středověké osídlení v Písku a jeho okolí, AVJČ 15, 117-138.

JOHN, J.-RYTÍŘ, L., 2007: Kněží hora (Priest Mound) - South Bohemian Fuji Yama. In: Archäologische Arbeitsgemeinschaft Ostbayern/West- und Südböhmen, 16. Treffen, 21. bis 24. Juni 2006 in Plzeň-Křimice (Chytráček, M.-Gruber, H.-Michálek, J.-Rind, M. M.-Schmotz, K., edd.), 267-273. Rahden/ Westf.

KOUŘIL, P., 2016: Staří Mad’aři a jejich podíl na kolapsu a pádu Velké Moravy aneb Spojenci, sousedé, neprrátelé. In: Pád Velké Moravy aneb Kdo byl pohřben v hrobu 153 na Pohansku u Břeclavi (Macháček, J.-Wihoda, M., edd.), 102-143. Praha.

KRAJÍC, R., 2010: Hradiště Chýnov u Tábora. Archeologický výzkum 2007-2008 - Die archäologische Untersuchung am Burgwall Chýnov bei Tábor in den Jahren 2007-2008, AVJČ 23, 155-190.

KRATOCHVÍL, V.-ROST, J., 2000: Analýzy a metodika použitá k rozborům surové tuhy a tuhové keramiky z Němětic. In: Hradec u Němětic. Sídlo halštatské a raně středověké nobility v českobavorském kontaktním prostoru (Michálek, J.-Lutovský, M., edd.), 243-249. Strakonice - Praha.

KUNA, M.-PROFANTOVÁ, N. a kol., 2005: Počátky raného středověku v Čechách. Archeologický výzkum sídelní aglomerace kultury pražského typu v Roztokách. Praha.

LUTOVSKÝ, M., 1990: Zjišt’ovací výzkum na hradišti u Kuklova, o. Brloh, okr. Český Krumlov - Feststellungsgrabung auf dem Burgwall bei Kuklov, Gemeinde Brloh, Bezirk Český Krumlov, AVJČ 7, 83-96.

- 1990a: Slovanské pohřebiště v Bělčicích, okr. Strakonice, AVJČ 9, 49-68.

- 1993: Raně středověké nálezy z jižních Čech ve sbírkách Národního muzea v Praze. Zprávy ČAS Supplément 21. Praha.

- 1995: Zur südböhmischen Keramik des Frühmittelalters: Quellenbestand und Fragestellung. In: Slawische Keramik in Mitteleuropa vom 9. bis zum 11. Jahrhundert - Terminologie und Beschreibung. II. Internationale Tagungen in Mikulčice (Poláček, L., ed.), 223-230. Brno.

- 1999: Odraz mocenských změn 10. století ve struktuře jihočeských hradišt', ASČ 3, 283-291.

- 2011: Jižní Čechy v raném středověku. Slovanské osídlení mezi Práchní a Chýnovem. Příbram.

LUTOVSKÝ, M.-MICHÁLEK, J., 1999: Nové nálezy z hradiště u Libětic, okr. Strakonice, AVJČ 12, 61-67.

MENŠÍK, P.-KRÁL, V., 2017: „Kněží hora“ u Katovic. Raně středověká pevnost nad řekou Otavou z pohledu archeologického bádání. Strakonice.

MENŠÍK, P.-PLZÁK, J., 2018: Grodzisko „Kněží hora“ koło Katovic (region południowych Czech) w świetle lotniczego skaningu laserowego. In: Lotnicze skanowanie laserowe jako narzędzie archeologie. Archaeologica Hereditas 11 (Gojda, M.-Kobyliński, Z., edd.), 279-288. Warszawa.

MENŠÍK, P.-PROCHÁZKA, M.-KRÁL, V., 2018: Der frühmittelalterliche Burgwall „Kněží hora“ bei Katovice (Bezirk Strakonice/CZ). Ein übergemeinschaftliches Zentrum mit Hinweisen auf ,fremde“ Kontakte, Fines Transire 27, 265-275.

MENŠÍK, P. et al., v přípravě: Menšík, P.-Čapek, L.-Hložek, J.-Kočár, P.-Sůvová, Z.-Hošek, J., Die Höhensiedlung und der Burgwall Katovice „Kněží Hora“. Ein überregionales Zentrum im urzeitlichen und frühmittelalterlichen Südböhmen, Archaeologische Korrespondenzblatt. 
MICHÁLEK, J., 1981: Muzeum středního Pootaví ve Strakonicích. Katalog pravěké sbírky. Zprávy ČAS 22. Praha.

- 1983: Záchranný výzkum ve Vodňanech, okres Strakonice, část 1 - výzkum v roce 1979 - Die Rettungsgrabung in Vodňany, Bezirk Strakonice (Teil 1 - Grabung 1979), AVJČ 1, 29-53.

- 1986: Záchranný výzkum ve Vodňanech, okres Strakonice (část 2 - pokračování výzkumu v roce 1981) Die Rettungsgrabung in Vodňany, Bezirk Strakonice (Teil 2 - Fortsetzung der Grabung im Jahre 1981), AVJČ 3, 17-73.

MICHÁLEK, J.-LUTOVSKÝ, M., 2000: Hradec u Němětic. Sídlo halštatské a raně středověké nobility v českobavorském kontaktním prostoru. Strakonice - Praha.

PÍČ, J. L., 1909: Starožitnosti země České III/1. Čechy za doby knížecí. Praha.

PRINCOVÁ-JUSTOVÁ, J., 1994: Die burgwallzeitliche Keramik aus Libice nad Cidlinou. In: Slawische Keramik in Mitteleuropa vom 8. bis zum 11. Jahrhundert, Internationale Tagungen in Mikulčice I (Staňa, Č., ed.), 193-205. Brno.

PROFANTOVÁ, N., 1997: K novějším nálezům z hradiště Libětice, okr. Strakonice - Neueste archäologische Funde vom Burgwall Hradiště bei Libětice, Kreis Strakonice, AVJČ 10, 26-38.

- 2016: Chronologie časně slovanského a starohradištního osídlení Čech na př́ikladu Prahy a jejího zázemí. In: Praha archeologická (Boháčová, I.-Šmolíková, M., edd.), 129-146. Praha.

SKLENÁ̌̌, K., 2007: August Česlav Ludikar, průkopník archeologie na Strakonicku, AVJČ 20, 45-64.

-2011: Pravěké a raně středověké nálezy v Čechách do roku 1870. Pramenná základna romantického období české archeologie. Fontes Archaeologici Pragenses 36. Praha.

- 2012: Hradiště jako předmět studia v počátcích české archeologie, ASČ 16, 497-611.

ŠPAČEK, K., 1861: O předhistorických hradištích a valích v Čechách, PA VI, 254-263.

SVĚTLÍK, I., 2018: Zpráva o výsledku radiokarbonového datování na základě dvou zuhelnatělých dřev dubu. Zpráva ulož. v archivu KAR ZČU v Plzni, Praha.

THOMOVÁ, Z., 1998: Frühmittelalterliche Graphittonkeramik aus Südböhmen. In: Frühmittelalterliche Graphittonkeramik in Mitteleuropa - Naturwissenschaftliche Keramikuntersuchungen. IV. Internationale Tagungen in Mikulčice (Poláček, L., ed.), 213-215. Brno.

VOCEL, J. E., 1865. Keltické ohrady, PA VI, 254-263.

WIHODA, M., 2016: Druhý život mojmírovských knížat. In: Pád Velké Moravy aneb Kdo byl pohřben v hrobu 153 na Pohansku u Břeclavi (Macháček, J.-Wihoda, M., edd.), 144-165. Praha.

WOLDŘICH, J. N., 1874. Verschlackte Steinwälle und andere urgeschichtliche Bauten in der Gegend von Strakonic, Mittheilungen der Anthropologischen Gesellschaft in Wien 4, 189-201.

ZAVŘEL, P., 1999: Současný stav výzkumu doby římské a doby stěhování národů v jižních Čechách - Der gegenwärtige Foschungsstand der römischen Kaiserzeit und der Völkerwanderungszeit in Südböhmen, AR LI, 468-516.

ZEHETMAYER, R., 2016: Rakouské Podunají kolem roku 900. In: Pád Velké Moravy aneb Kdo byl pohřben v hrobu 153 na Pohansku u Břeclavi (Macháček, J.-Wihoda, M., edd.), 73-101. Praha.

\section{Zusammenfassung}

\section{Frühmittelalterliche Keramik vom Burgwall Kněží hora (Pfaffenberg) bei Katovice (Be- zirk Strakonice)}

Kněží hora (Pfaffenberg) bei Katovice (Bezirk Strakonice) zählt zu den größten südböhmischen frühmittelalterlichen Burgwällen aus der Zeit des 9. bis Anfang 10. Jahrhunderts, dem die Forscher bereits ab der zweiten Hälfte des 19. Jahrhunderts Aufmerksamkeit gewidmet haben. Die bisherigen Erkenntnisse über den Burgwall und seine Datierung stützten sich vor allem auf die von B. Dubský im Jahr 1946 durchgeführte Grabung. Aus seiner Grabung stammende Keramikfunde sowie ein bei Oberflächensammlungen gewonnener, nicht stratifizierter Fundkomplex legten die Existenz des Burgwalls in den Zeitraum zwischen Ende des 8. bis zur Wende des 9. und 10. Jahrhunderts. Der Burgwall ist ähnlich wie auch andere Burgwälle in der Region des mittleren Flussgebietes der Otava (Libětice, Řepice, Němětice) offenbar Anfang des 10. Jahrhunderts untergegangen, worauf die an allen Burgwällen festgestellte Zerstörungsbrandschicht der Wälle hindeutet. 
In den Jahren 2016-2017 erfolgte am Burgwall eine nicht destruktive und nur wenig destruktive Grabung, die auf Probesondierungsgrabungen an den Stellen der Akropolis beschränkt war, die von der Waldwirtschaft und illegalen Aktivitäten mit Metalldetektoren gestört waren. Insgesamt wurden 12 Sondierungsschnitte gelegt. Auch die obere Partie der Zerstörungsschicht des Holz-Lehm-Walles mit vorderer Steinverkleidung im nordwestlichen Teil der Akropolis wurde sondiert (Sondierschnitt 7). Von einigen am Fuß des Außenwalls gelegten Sondierschnitten (besonders 1, 5 und 8) stammten zahlreiche Fundkomplexe mittelalterlicher Keramik, die zusammen mit den bei den älteren Grabungen Dubskýs und den Oberflächensammlungen gewonnenen Fundkomplexen zum Gegenstand einer detaillierten Bearbeitung und Auswertung wurden.

Die frühmittelalterliche Keramik vom Burgwall in Katovice weist typologische und morphologische Merkmale sowie Zierelemente auf, die für die Mittelburgwallzeit typisch sind. Am meisten kamen Topfformen mit Eierstabprofilierung und s-förmig gebogenem Topfkörper vor. Dabei am häufigsten vertreten waren einfach profilierte, schräg abgeschnittene Ränder und Ränder mit langgezogener Unter- und Oberkante und leichter Kehlung der oberen Kantenfläche. Von den Ziermotiven traten Kammwellen, in geringerem Maße Kammeinstiche und vereinzelte plastische Leisten am häufigsten auf, die als progressivere Elemente angesehen und in das 10. Jahrhundert datiert werden können. Man begegnet auch einer Kombination von mehreren Zierelementen an Topfschulter und Topfbauch.

Die Datierung des Keramikensembles stützt sich auf Schlussfolgerungen, die anhand einer Auswertung des größten Fundkomplexes frühmittelalterlicher (mittelburgwallzeitlicher) Keramik vom Burgwall bei Němětice gezogen wurden, wo wir eine Reihe vergleichbarer Elemente antreffen (Art der Randprofilierung und Zusammensetzung der Ziermotive). Ein gewisser Datierungsindikator für den Fundkomplex vom Burgwall Katovice ist das Fehlen von Graphitkeramik, die in Südböhmen erst im Laufe des 10. Jahrhunderts mit der aufkommenden Burgwallzeit vorkommt.

Die in den Jahren 2016 und 2017 durchgeführte systematische Grabung und die Analyse der mittelburgwallzeitlichen Keramik lieferten keine Belege für die in der Fachliteratur schon an das Ende des 8. Jahrhunderts gelegten Anfänge einer Besiedelung. Es zeigt sich hingegen, dass der Schwerpunkt der meisten Keramikfunde in die Zeit des 9. Jahrhunderts fällt, wobei eine Besiedelung auch durch die von der Holzkohle des Holz-Lehm-Walles gewonnenen Radiokarbondaten bestätigt wird. Die chronologische Obergrenze kann nicht weiter als in den Verlauf des 10. Jahrhunderts gelegt werden. Dem jüngeren Horizont können einige Zierelemente zugeordnet werden wie Wellenlinien, einfache Ritzrillen und plastische Leisten oder einige kompliziertere und für die Jungburgwallzeit typischere Randprofilierungen mit langgezogener Ober- und Unterkante und leichter Kehlung der oberen Kantenfläche.

Der vorliegende Beitrag wurde gefördert von den Projekten SGS-2018-010: Burgwall „Kněží Hora“ bei Katovice, Bez. Strakonice. Das Aussagepotenzial der Fundstelle auf Grundlage multidisziplinärer Forschung und NAKI II DG18PO2OVV020: Hochmittelalterliche Keramik als Bestandteil des beweglichen Kulturerbes.

Mgr. Ladislav Čapek, Ph.D., Katedra archeologie Filozofické fakulty Západočeské univerzity v Pzni, Sedláčkova 15, 30614 Plzeň, Česká republika, capekla@kar.zcu.cz

PhDr. Petr Menšík, Ph.D., Katedra archeologie Filozofické fakulty Západočeské univerzity v Pzni, Sedláčkova 15, 30614 Plzeň, Česká republika,pmensik@kar.zcu.cz 
